\title{
CONTEÚDO E ALCANCE DA DECISÃO DO STF SOBRE A LEI DE IMPRENSA NA ADPF 130
}

\author{
Thales Morais da Costa
}

CONTENT AND SCOPE OF STF'S RULING ON THE PRESS

ACT IN THE ADPF 130

\section{RESUMO}

PROPÕE-SE UMA ANÁLISE CRÍTICA DA DECISÃO DO STF QUE JULGOU PROCEDENTE A ADPF 130, VOLTADA CONTRA A LEI DE IMPRENSA. NA PRIMEIRA PARTE, BUSCA-SE COMPREENDER $O$ CONTEÚDO DESSA DECISÃO COM O AUXÍLIO DE UMA TABELA DE CONTRAPOSIÇÃO DOS MOTIVOS QUE INTEGRAM OS VOTOS DE CADA MINISTRO. CONSTATA-SE QUE O ÚNICO FUNDAMENTO MAJORITÁRIO PARA A PROCEDÊNCIA DA AÇÃO FOI O DA INCOMPATIBILIDADE DA INTEGRALIDADE DA LEI DE IMPRENSA COM A CONSTITUIÇÃO DE 1988. O PONTO CONTROVERTIDO RELATIVO AO DEVER DO ESTADO DE TOLERAR A DIVULGAÇÃO DE QUALQUER INFORMAÇÃO NÃO ALCANCCOU A MAIORIA DOS VOTOS E NÃO GOZA DA AUTORIDADE DAS DECISÕES DO STF. NA SEgUNDA PARTE, EXAMINA-SE O ALCANCE DA DECISÃO PROFERIDA NA ADPF 130, TENDO COMO MATERIAL DE PESQUISA AS RECLAMAÇÕES AJUIZADAS SOB 0 ARGUMENTO DE VIOLACCÃO DE SUA AUTORIDADE. INICIALMENTE, VERIFICA-SE QUE A NÄO RECEPÇÃO DA LEI DE IMPRENSA CONDUZ A IMPOSSIBILIDADE DE SUA APLICAÇÃO, SEM QUE SE TENHA ESCLARECIDO, ATÉ O MOMENTO, SE A JURISPRUDÊNCIA DA OFENSA REFLEXA OU INDIRETA À CONSTITUICC̃̃O CONTINUA A APLICAR-SE EM MATÉRIA DE IMPRENSA. EM SEGUIDA, OBSERVA-SE QUE, EMBORA NÃO TENHA HAVIDO MAIORIA ACERCA DO SUPOSTO DEVER DE TOLERAR A DIVULGAÇÃO DE QUALQUER INFORMAÇÃO, O STF VEM CONCEDENDO LIMINARES EM ALGUMAS RECLAMAÇÕES, O QUE REFORÇA A IMPORTÂNCIA DE SE COMPREENDER O QUE FOI DECIDIDO NA ADPF EM QUESTÄO.

\section{PALAVRAS-CHAVE}

LEI de Imprensa; NÃO RECEPÇÃo; CONTROLE de constitucionalidade; Supremo Tribunal Federal.

\section{ABSTRACT}

THIS PAPER PROPOSES A CRITICAL ANALYSIS OF THE SUPREME COURT (STF) DECISION THAT UPHELD THE ADPF 130, DIRECTED AGAINST THE PRESS ACT. IN THE FIRST PART, WE SEEK TO UNDERSTAND THE CONTENT OF THAT DECISION WITH THE AID OF A TABLE COMPARING THE REASONS ADOPTED BY EACH JUDGE. IT APPEARS THAT THE INCONGRUENCE BETWEEN THE WHOLE PRESS ACT AND THE CONSTITUTION OF 1988 WAS THE ONLY BASIS TO REACH THE MAJORITY. THE POINT AT ISSUE CONCERNING THE NON-INTERFERENCE ON FREE SPEECH DID NOT REACH THE MAJORITY AND DOES NOT HAVE THE AUTHORITY OF THE SUPREME COURT DECISIONS.

THE SECOND PART EXAMINES THE SCOPE OF THE DECISION IN ADPF 130, THROUGH THE ANALYSIS OF SEVERAL COMPLAINTS FILED ON THE GROUNDS OF VIOLATION OF THE AUTHORITY OF SUPREME COURT RULING. INITIALLY, IT APPEARS THAT THE NON-RECEPTION OF THE PRESS ACT LEADS TO THE IMPOSSIBILITY OF ITS APPLICATION, WITHOUT HAVING CLEAR, YET, IF THE DOCTRINE CALLED "REFLEX OR INDIRECTLY VIOLATION OF THE CONSTITUTION" CONTINUES TO APPLY IN RESPECT OF THE PRESS. THEN, IT IS OBSERVED THAT, ALTHOUGH THERE WAS NO MAJORITY ON THE SUPPOSED DUTY OF NON-INTERFERENCE ON FREE SPEECH, STF KEEPS GRANTING INJUNCTIONS IN SOME COMPLAINTS, WHICH REINFORCES THE IMPORTANCE OF UNDERSTANDING WHAT WAS DECIDED IN ADPF 130.

\section{KEYWORDS}

PRESS ACT; NON-RECEPTION BY THE NEW CONSTITUTION; JUDICIAL REVIEW; FEDERAL SUPREME COURT. 


\section{INTRODUÇÃO}

O presente trabalho analisa a decisão proferida pelo Supremo Tribunal Federal (STF) na Arguição de Descumprimento de Preceito Fundamental n. 130 (ADPF 130), ${ }^{1}$ que concluiu pela procedência da ação, por se entender que a Lei n. 5.250 de 9 de fevereiro de 1967, que "regula a liberdade de manifestação do pensamento e de informação", conhecida como "lei de imprensa", não teria sido recepcionada pela Constituição de 5 de outubro de 1988 (CF). Busca-se compreender qual seria o conteúdo e o alcance dessa decisão.

Trata-se de questão de grande atualidade. Em 13 de novembro de 2012, o Conselho Nacional de Justiça (CNJ) criou o "Fórum Nacional do Poder Judiciário para a liberdade de imprensa", encarregado de realizar, entre outros, o "levantamento estatístico das ações judiciais que tratem das relações de imprensa" e "o estudo de modelos de atuação da magistratura em países democráticos, que possam facilitar a compreensão de conflitos que digam respeito à atuação da imprensa” (art. 2 , Resolução n. 163, 2012). O pano de fundo para a criação desse órgão, como reconheceu o então presidente do CNJ, Min. Ayres Britto, é o julgamento da ADPF $130^{2}$ e o contexto de sua execução pelos tribunais brasileiros.

Tratar do tema da execução de uma decisão do STF pressupõe que se saiba com clareza o que teria sido decidido e, antes de tudo, o que seria uma "decisão". O STF tem afirmado que sua “decisão” não se limita ao que consta no dispositivo. Também a integrariam os fundamentos necessários ou determinantes (ratio decidendi) do dispositivo. ${ }^{3}$ Não se colocará em questão, aqui, a constitucionalidade dessa jurisprudência, cabendo lembrar, apenas, que parte da doutrina entende ser impossível dar à motivação o caráter de "decisão" (PFERSMANN, 2012). Partindo do fato de que, para o STF, a ratio decidendi integra a autoridade da "decisão", cumpre perguntar quais seriam os fundamentos necessários ou determinantes suscetíveis de integrar a decisão de procedência da ADPF 130. Colocar essa pergunta requer que se possa identificar claramente os motivos que levaram o tribunal, em seu conjunto, a julgar procedente a ADPF 130. Examinar esses diferentes temas significa indagar qual seria o conteúdo da decisão do STF - e esse é o objeto da primeira parte do presente estudo.

Uma vez delimitado o conteúdo do acórdão do STF, cumpre indagar qual seria seu alcance. Quais são as decisões, as matérias e as autoridades que se encontrariam vinculadas ao julgado do STF? É o que será examinado na segunda parte.

\section{ANÁlise do CONTEÚdo dA DECisÃo PROFERIDA NA ADPF I30}

Antes de iniciar a investigação sobre o conteúdo da ADPF 130, é necessário estabelecer um método adequado para essa investigação. Para tanto, é importante levar em consideração a especificidade do modo como são redigidos os acórdãos do STF. 


\section{I O MÉTODO DE REDAÇÃO DAS DECISÕES DO STF E SUAS CONSEQUÊNCIAS SOBRE A DETERMINAÇÃO DO CONTEÚDO DESSAS DECISÕES}

A peculiaridade do método de redação dos acórdãos do STF é que não existe a prática de elaboração conjunta de um voto que seja representativo da opinião do tribunal. $\mathrm{O}$ voto do relator retrata a opinião de um ministro, à qual os demais podem ou não aderir. Há casos em que cada ministro elabora o seu próprio voto, concordando com ou divergindo da opinião do relator. Ao final da sessão, tem-se uma soma de votos individuais que definem o resultado do julgamento. Caso a posição adotada pelo relator seja a vencedora, é ele quem redige a ementa do acórdão. Caso o relator original seja vencido, o ministro que abriu a divergência - a qual se revelou, ao final, ser a posição da maioria - atua como "relator para o acórdão".

Nos casos em que cada ministro elabora um voto em separado, é frequente que os votos vencedores coincidam apenas quanto à conclusão, distinguindo-se com relação aos fundamentos. Tendo cada ministro redigido o seu próprio voto, é difícil identificar onde se encontra a ratio decidendi, ou seja, o fundamento que teria levado o tribunal, como um órgão colegiado, a adotar certa decisão. É necessário examinar cada um dos votos e comparar as respectivas fundamentações para verificar se existe algo de comum entre elas.

A situação é radicalmente diferente nos tribunais constitucionais europeus e nos Estados Unidos da América. Veja-se o caso da França, que conhece um método de redação das decisões diferente do adotado no Brasil. Com efeito, naquele país, o relator elabora um projeto de decisão, que é submetido aos demais juízes durante uma sessão de julgamento secreta. Cada juiz faz observações e, conforme o caso, sugere mudanças tanto no que diz respeito à conclusão quanto no que tange à fundamentação. Cada uma das propostas de mudança é objeto de votação e, em função do resultado, o trecho em questão do projeto do relator é reescrito pelo colegiado. Obtém-se, ao final, uma opinião coletiva sobre o caso, que é encaminhada para publicação. O projeto do relator, enquanto tal, não é publicado, tampouco as propostas de redação que não foram acolhidas pelo colegiado. Publica-se apenas a decisão tal como deliberada pelo tribunal. Essa situação vale seja nos casos de decisão unânime, seja nos casos de decisão por maioria, visto que, mesmo neste último caso, apenas a posição da maioria é publicada. A opinião dos juízes eventualmente vencidos nunca acompanha a publicação do acórdão. Como se vê, esse método de redação faz com que o acórdão seja acolhido pelo público como sendo a posição do tribunal em seu conjunto.

A Alemanha encontra-se em situação muito similar à da França, pois a redação das decisões judiciais também é fruto de trabalho coletivo, o que leva os juízes a encontrar um compromisso não apenas quanto ao dispositivo, mas também com relação ao fundamento de suas decisões. Também aqui cabe ao relator submeter um projeto de decisão ao órgão colegiado. Cada parágrafo é analisado e votado. Se o relator ficar vencido em 
algum ponto, deve reescrever o trecho em questão e submeter novo projeto ao órgão colegiado na sessão de julgamento seguinte. Nova votação ocorre e, se o novo projeto do relator permanecer dissonante da decisão da maioria, cumprir-lhe-á redigir um terceiro projeto. E, assim, é possível haver diversas sessões de julgamento até que se tenha uma redação que seja aceita pelo tribunal. Uma vez definida a redação final do acórdão, ele deve ser assinado por todos os juízes que o aprovaram. A diferença mais importante com relação ao que ocorre na França consiste em que, em havendo decisão não unânime, são divulgados os votos vencidos ao lado da opinião da maioria (sistema vigente a partir da reforma de 21 de dezembro de 1970). No entanto, mesmo no caso de decisão não unânime, o voto majoritário é fruto de uma deliberação coletiva, o que permite identificá-lo enquanto a opinião do tribunal em seu conjunto.

Nos Estados Unidos da América, a técnica de leitura em sequência de votos individuais (seriatim opinions) - em vigor nos primeiros acórdãos adotados pela instância judicial máxima daquele país - foi abandonada em 1801, sob a presidência do juiz Marshall. Desde então, uma vez encerrados os debates e definida a solução a ser dada ao caso concreto, o presidente do tribunal indica um dos juízes para redigir o que se denomina a opinion of the Court. Essa opinion - redigida individualmente por um juiz, legitimado a manifestar a opinião de todo o órgão colegiado pela indicação que recebeu do presidente do tribunal - contém a fundamentação que leva o tribunal, em seu conjunto, a adotar determinada decisão. Sendo o tribunal composto por nove juízes, uma opinion of the Court representa o entendimento de, no mínimo, cinco juízes. Como regra geral, os demais juízes eximem-se de elaborar voto próprio, exceto no caso de serem vencidos, hipótese em que elaboram voto dissidente. Mas há casos em que os juízes integrantes da maioria estão de acordo quanto à solução a dar ao caso concreto, mas em desacordo quanto à fundamentação. Nesses casos, o presidente do tribunal indica um dos juízes para redigir o que se denomina o judgement of the Court ${ }^{4} \mathrm{e}$ abre aos demais juízes a possibilidade de redigir um voto em separado. No voto em separado (concurring opinion), o magistrado explicita as razões específicas que o levaram a aderir à conclusão da maioria sem ratificar a fundamentação. Nos casos intermediários, ou seja, naqueles em que uma parte da fundamentação do relator é subscrita pela maioria e a outra parte não, o acórdão diferencia claramente, dentro do voto do relator, quais parágrafos constituem a opinion e quais representam apenas o judgement. ${ }^{5}$ Essa preocupação bastante nítida com a diferenciação entre opinion e judgement explica-se pelo fato de que apenas aquela traduz o entendimento do tribunal em seu conjunto. Por via de consequência, é somente a opinion que possui valor de precedente.

Como se vê, a técnica de redação adotada nesses três países e em muitos outros ${ }^{6}$ revela a preocupação de divulgar o entendimento do tribunal enquanto órgão colegiado, não enquanto reunião de votos individuais.

Já o acórdão prolatado na ADPF 130 é um exemplo bastante interessante de decisão composta por votos individuais, cada um com sua respectiva fundamentação. 
Apenas um ministro adotou integralmente as razões do relator, qual seja, o Min. Eros Grau. Os demais avançaram suas próprias razões para chegar à conclusão que chegaram. Da pluralidade de motivações, decorre a dificuldade na compreensão de qual seria o entendimento do tribunal em seu conjunto acerca da liberdade de imprensa e de seus eventuais limites. Observe-se o seguinte trecho:

Interdição à lei quanto às matérias nuclearmente de imprensa, retratadas no tempo de início e de duração do concreto exercício da liberdade, assim como de sua extensão ou tamanho de seu conteúdo. (...) o Poder Público somente pode dispor sobre matérias lateral ou reflexamente de imprensa, respeitada sempre a ideia-força de que quem quer que seja tem o direito de dizer o que quer que seja. Logo, não cabe ao Estado, por qualquer dos seus órgãos, definir previamente o que pode ou o que não pode ser dito por indivíduos e jornalistas. ${ }^{7}$

Uma vez que o objeto dessa citação integra a própria ementa da ADPF 130, aquele que lê o acórdão pela primeira vez é levado a crer que essa seria a posição do tribunal. Em outros termos, que esse seria um fundamento necessário do dispositivo, suscetível de integrar a "decisão" como um todo e cujo respeito poderia ser imposto "às autoridades e aos órgãos responsáveis pela prática dos atos questionados” (art. 10, Lei n. 9.882).

No entanto, a análise mais detida do caso revela que a compreensão do sentido do acórdão é objeto de controvérsias entre os próprios ministros do STF. Tanto durante o julgamento da ADPF quanto poucos meses depois, houve divergências claras acerca do que teria sido decidido.

Confira-se o seguinte debate ocorrido durante o julgamento: Min. Gilmar Mendes (GM): “Quanto à afirmação feita, e agora já refeita, a meu ver, de que nenhum Estado Democrático teria lei de imprensa, nós sabemos que isso não corresponde à verdade estrita dos fatos. Há muitos países democráticos, assim considerados, com lei.” Min. Carlos Britto (CB): “Essa afirmação não está no meu voto.” GM: "Não, isso foi discutido, inclusive, inicialmente.” Min. Cármen Lúcia (CL): "Eu fiz afirmativa até contrária, hoje, exatamente no levantamento que fiz, que Estados Democráticos têm.” (ADPF 130, p. 275).

Seis meses depois, nova divergência quanto ao sentido dos votos na ADPF 130: GM: "Realmente, precisamos nominar o que foi objeto de decisão e aquilo que está coberto pelo efeito vinculante, sem dúvida nenhuma. Até porque houve considerações do Ministro Britto que, com certeza, não mereceram o apoio da maioria. Por exemplo, a afirmação de Sua Excelência segundo a qual não poderia haver lei regulando a imprevisibilidade nesse sentido." CB: "Mas eu não afirmei isso.”8

O caso mais evidente das dificuldades dos próprios ministros em entender qual seria o conteúdo da decisão na ADPF 130 envolve o voto proferido pelo Min. Lewandowski. 
O trecho de seu voto que se encontra nas páginas 102 e 103 da ADPF 130 foi interpretado em sentidos diametralmente opostos por dois de seus pares. Para um dos julgadores, o ministro em questão teria acompanhado o relator apenas quanto à conclusão, divergindo no que tange às razões de seu convencimento. Para o outro, o Min. Lewandowski teria acompanhado o relator da ADPF 130 também no que concerne à fundamentação.

Confira-se: Min. Cezar Peluso (CP): “[o Min. Lewandowski reconheceu, na ADPF,] a coexistência teórica, enquanto situados no mesmo plano de eficácia plena e aplicabilidade imediata, dos direitos de liberdade de expressão, pensamento e informação (...) e a inviolabilidade da intimidade, da vida privada, da honra e da imagem (...), concluindo pela mesma necessidade de a decisão do caso concreto guiar-se pelo princípio da proporcionalidade (fls. 102 e 103 [da ADPF 130]), donde, por implicitude, haver negado caráter absoluto e irrestrito à liberdade de imprensa” (Rcl 9.428, p. 188). Para o Min. Britto, "não foi bem assim” (Rcl 9.428, p. 214). Para apoiar sua tese, ele cita (na p. 213 da Rcl 9.428) o mesmo trecho do voto do Min. Lewandowski acrescido de um parágrafo constante na p. 105 da ADPF 130 - para, em seguida, concluir: "Evidentemente, que [ele] estava falando da insubmissão da imprensa à regulação por lei quanto às coordenadas de conteúdo.” (ADPF 130, p. 213).

Divergência semelhante é verificada acerca do voto que o Min. Direito proferiu na ADPF 130 (páginas 85 a 94). Na Reclamação n. 9.428, os ministros Britto (p. 212) e Peluso (p. 187) interpretaram esse voto em sentidos opostos.

Tais elementos já permitem ver quão difícil é a tarefa de conhecer o conteúdo de um acórdão do STF. A fim de saber qual é a posição do tribunal enquanto órgão colegiado, é preciso levar em consideração todos os votos, não apenas o do relator. É necessário, ademais, cotejar a fundamentação do voto do relator com os motivos expostos pelos demais ministros, a fim de verificar se houve algum argumento comum que os conduziu todos, ou a maioria, a votar no sentido que votaram.

Para responder a essa dificuldade, foi elaborada a tabela em anexo, em que foram escolhidos nove temas que representam as principais questões debatidas no julgamento da ADPF 130. Para cada tema, buscou-se formular uma pergunta que levasse a uma resposta clara ( $\mathrm{sim} /$ não), citando, na sequência de cada resposta, o trecho do voto do ministro mais diretamente relacionado com a questão formulada. Ver-se-á que nem todos os votos trataram integralmente dos nove temas. Alguns temas foram examinados apenas por alguns ministros, o que é um elemento a mais que revela a dificuldade da tarefa de compreender qual teria sido a posição do tribunal em seu conjunto. Nos casos em que o voto de determinado ministro não permite compreender qual seria sua opinião sobre o tema em questão, indicou-se na tabela "não se manifesta de modo expresso" ou "não se pronuncia de modo expresso".

Também integram a tabela perguntas relativas a outros processos julgados pelo STF, em especial as reclamações em que se alegava o descumprimento da “decisão” proferida 
na ADPF 130. A tabela também inclui uma pergunta relativa ao HC n. 82.424-2, de cujo julgamento participaram seis dos onze ministros que votaram na ADPF 130. Esse caso é anterior ao julgamento da ADPF 130, mas ainda assim se justifica sua inserção no presente estudo, pois permite compreender com maior profundidade o modo como cada ministro concebe a liberdade de imprensa.

Essa tabela não tem, evidentemente, a pretensão de exaurir a riqueza dos votos que compuseram a ADPF 130. Ela foi elaborada com o objetivo puramente acadêmico de ser um instrumento a mais na compreensão do que teria sido decidido pelo STF. Seu objetivo principal é contribuir para a resposta da seguinte questão: qual é o conteúdo da decisão do STF na ADPF 130 ou, de modo mais específico, teria havido algum fundamento consensual entre os membros da maioria de sete a quatro suscetível de integrar o dispositivo da ADPF 130 e de gozar da autoridade de “decisão" do STF?

\section{I.2 O ENTENDIMENTO MAJORITÁRIO DE NÃO RECEPÇÃO DA LEI N. 5.250 PEla CONSTITUIÇÃo DE 1988}

À indagação sobre o conteúdo da decisão do STF, há uma resposta incontroversa no próprio dispositivo do acórdão: "os Ministros do Supremo Tribunal Federal [acordam] em julgar procedente a ação” (ADPF 130, p. 11). Esse dispositivo encontra-se na parte do acórdão denominada “acórdão" (ADPF 130, p. 11 a 12), que vem logo após a ementa. Essa parte do acórdão, que se poderia chamar de "acórdão em sentido estrito", contém o resultado do julgamento, tal como proclamado pelo presidente do tribunal. Por ser proclamado pela autoridade que representa o tribunal em seu conjunto, o "acórdão em sentido estrito" é especialmente importante para o presente estudo, pois indica claramente qual é a solução dada ao caso pelo tribunal.

Porém, com exceção desta parte, todos os demais componentes da decisão do STF são redigidos não por quem representa o tribunal em seu conjunto, mas pelos ministros, que proferem votos individuais. Até mesmo a ementa, como se viu, é redigida individualmente pelo relator, não pelo conjunto de ministros integrantes da maioria. Diante da ausência de um método coletivo de redação dos acórdãos do STF, aspectos extremamente importantes de uma decisão somente podem ser encontrados nos votos individuais.

Isso vale até mesmo para a questão de saber em que termos a ação foi julgada procedente, ou seja, o que teria sido declarado, desconstituído, constituído ou ordenado pelo tribunal em seu conjunto. Uma vez que, na ADPF 130, o "acórdão em sentido estrito" limita-se a afirmar que a ação é julgada procedente "nos termos do voto do Relator e por maioria de votos" (p. 12), é preciso recorrer aos votos que integram a maioria. Ora, observando-se a tabela em anexo (v. questão n. 1 (Q 1)), constata-se que nem todos os votos integrantes da maioria indicam, de modo preciso, em que termos a ação foi julgada procedente. É possível classificar esses votos em três grupos: (i) aqueles que afirmam claramente que, diante da incompatibilidade total da lei 
de imprensa com a Constituição de 1988, a ação seria julgada procedente para declarar a não recepção da Lei n. 5.250 como um todo; (ii) os que consideram haver incompatibilidade total entre a lei e a Constituição e que julgaram a ação "procedente" sem especificar em que termos; e (iii) aqueles que, embora considerem haver compatibilidade de alguns artigos da lei com a Constituição, concluem pela procedência da ação para declarar a não recepção da Lei n. 5.250 como um todo (v. Q 1 e Q 2).

Os dois primeiros grupos reúnem seis ministros. Há, portanto, uma opinião majoritária que julga a ação procedente por entender que haveria incompatibilidade total da Lei n. 5.250 com a Constituição de 1988. Desses seis ministros, quatro disseram expressamente que a incompatibilidade levava à declaração de não recepção total da lei (Min. Carlos Britto, Cármen Lúcia, Eros Grau e Ricardo Lewandowski). Os outros dois não especificaram em que termos julgavam a ação procedente (Min. Celso de Mello e Menezes Direito, v. Q 1). Presume-se que tenham seguido a conclusão proposta pelo relator, qual seja, a de declarar a não recepção total da lei, mas isso não consta expressamente de seus votos.

O terceiro grupo é formado por apenas um ministro (Min. Cezar Peluso), que votou pela não recepção total da lei, mas, ao mesmo tempo, admitiu que alguns artigos da lei seriam "absolutamente compatíveis com o ordenamento constitucional vigente" (ADPF 130, p. 123). Se ele chegou à mesma conclusão que o relator, não foi por entender que o conteúdo da Lei n. 5.250 seria totalmente incompatível com a Constituição de 1988 (v. tabela, Q 2). Foi simplesmente por uma questão prática: "talvez não fosse prático manter vigentes alguns dispositivos de um sistema que se tornou mutilado. A sobrevivência de algumas normas, sem organicidade, realmente poderia levar, na prática, a dificuldades" (ibidem, p. 123).

Observe-se que o argumento segundo o qual alguns artigos da lei de imprensa seriam compatíveis com a Constituição de 1988 foi adotado por outros três ministros (Min. Ellen Gracie, Joaquim Barbosa e Gilmar Mendes), que chegaram, porém, a uma conclusão diversa, julgando a ação parcialmente procedente (v. Q 1). Uma vez que a conclusão a que chegaram é diferente daquela adotada pela maioria, esses três juízes ficaram vencidos. O Min. Peluso, embora tenha apoiado seu voto em fundamentos semelhantes aos arrolados por esses três ministros (v. Q 2), valeu-se, no final de seu voto, de um argumento ligado à organicidade da lei para chegar à mesma conclusão que a maioria, qual seja, julgar a ação totalmente procedente.

Logo, foram seis ministros, e não sete, que entenderam haver total incompatibilidade entre o conteúdo da Lei n.5.250 e o conteúdo da Constituição de 1988, embora tenham sido sete os ministros a concluir pela procedência total da ação. A partir do momento em que seis ministros concordaram quanto à incompatibilidade da totalidade da lei de imprensa com a Constituição, tem-se aqui um fundamento necessário do dispositivo, na medida em que foi com base nesse motivo que o tribunal julgou a ação procedente. Esse fundamento integra, portanto, a "decisão" do STF, nos termos 
em que a jurisprudência desse mesmo tribunal vem interpretando a noção de "decisão" (cf. introdução supra).

Resta saber se haveria, entre os ministros do STF, um consenso quanto à razão pela qual a Lei n. 5.250 seria totalmente incompatível com a Constituição de 1988, ou seja, se haveria um único fundamento do fundamento ou se os ministros teriam entendido haver incompatibilidade total mediante argumentações diversas, insuscetíveis de ser reduzidas a um denominador comum.

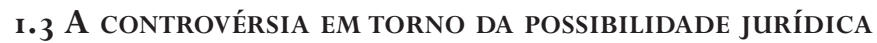
DE INTERVENÇÃo ESTATAL NO CONTEÚDO DA LIBERDADE DE IMPRENSA

Dentre as muitas respostas possíveis para a questão da possibilidade e da extensão da disciplina normativa da imprensa, quatro assumem especial relevo no contexto da ADPF 130. Todas elas reconhecem um papel importante ao Estado, mas se diferenciam entre si quanto à extensão desse papel e aos órgãos que seriam encarregados de exercê-lo.

A primeira resposta consiste em dizer que nenhum dos poderes da República pode dispor sobre o conteúdo da informação a ser publicada, cabendo ao judiciário pronunciar-se apenas sobre as matérias que o relator da ADPF 130 qualificou de "laterais" ou "reflexas" (como o direito de resposta e as ações de indenização), resolvendo os casos concretos através da aplicação direta da Constituição (resposta “A”). Dentro desse raciocínio, os poderes Legislativo e Executivo estariam proibidos de toda interferência na imprensa, até mesmo nas questões "laterais".

A segunda resposta consiste em dizer que seria possível ao Judiciário pronunciar-se não apenas sobre as matérias "laterais”, mas também sobre o conteúdo da informação, podendo decidir, através da aplicação direta da Constituição, pela proibição de divulgação de algumas informações (resposta "B”). Dentro desse raciocínio, os poderes Legislativo e Executivo permaneceriam proibidos de toda interferência na imprensa.

A terceira resposta seria defender que o legislador pode, sim, disciplinar a atividade da imprensa, mas apenas nas questões relativas à responsabilidade e ao direito de resposta e em outras questões "laterais" ou "reflexas", jamais sobre o conteúdo da publicação. Ao Judiciário caberia pronunciar-se sobre as questões "laterais", aplicando a legislação correspondente, bem como, eventualmente, dispor sobre o conteúdo da informação através da aplicação direta da Constituição (resposta “C”).

A quarta resposta seria sustentar que o Estado pode, através tanto do Legislativo quanto do Judiciário, dispor sobre as diferentes questões relativas à imprensa, inclusive sobre o conteúdo do que pode ou não ser publicado. Seria, então, possível ao Legislativo adotar, se assim entender, uma "lei de imprensa" em sentido amplo, estipulando, dentro do respeito da Constituição, que certas informações não possam ser divulgadas (resposta "D”).

O objetivo do presente estudo não é o de analisar qual dessas respostas seria a melhor nem se alguma delas teria sido escolhida pela Constituição de 1988. Busca-se 
apenas verificar se alguma delas foi subscrita pelo conjunto dos ministros integrantes da maioria de sete a quatro na ADPF 130.

I.3. I O CONTEÚdo DA DECISÃo NA ADPF I 30 :

A POSSIBILIDADE OU NÃO DE INTERVENÇÃO DO LEGISLATIVO

A resposta "A" identificada anteriormente encontra sua melhor expressão no voto do Min. Lewandowski. Com efeito, é em seu voto que se encontra a defesa mais veemente da desnecessidade e, até mesmo, da impertinência da intervenção do legislador em matéria de imprensa. Ele não apenas entende que a Constituição teria regulado a imprensa por inteiro (v. tabela, Q 4), como adere ao modelo fornecido por países nos quais a imprensa não seria, nos termos de seu voto, submetida a "qualquer disciplina legal" (Q 5). Ademais, contrariamente ao posicionamento adotado por muitos ministros integrantes da maioria, seu voto não menciona nenhum âmbito no qual a intervenção do legislador seria possível ou necessária (Q 6). Não se trata de omissão fortuita. Ao manifestar-se sobre o papel do legislador no âmbito do direito de resposta, ele afirma claramente que esse direito "não enseja disciplina legal apriorística" (Q 7). Sua posição afasta-se, portanto, da dos demais ministros, que afirmaram, de maneira quase unânime, que o direito de resposta pode ser objeto de regulamentação pelo legislador (Q 7). No entender do Min. Lewandowski, o art. $5^{\circ}$ da CF seria autoaplicável, não havendo "qualquer lacuna" (ADPF 130, p. 279), sendo que "o juiz determinará" (ibidem, p. 280) as questões em aberto sobre o direito de resposta e as "quatro instâncias recursais (...) certamente harmonizarão o tema, como fizeram com relação à ausência de tarificação no que tange à indenização por dano moral” (ibidem, p. 281-282).

Defende-se, assim, um entendimento que se aproxima da resposta "A". Esse não é, porém, um posicionamento majoritário, na medida em que os demais ministros entenderam que alguma forma de intervenção do Legislativo seria possível (v. tabela, Q 5 e 6), ainda que, como se verá no próximo tópico, não estejam todos de acordo quanto à extensão da atuação do legislador ou do Judiciário que seria autorizada pela Constituição.

Sendo assim, não há entendimento majoritário na ADPF 130 que afirme a impossibilidade de intervenção do Estado-legislador. Constata-se que as respostas "A" e "B" não representam o entendimento da maioria dos ministros. Resta saber se a maioria do STF teria chegado a um entendimento com relação à extensão da interferência do Estado.

\section{I.3. 2 A eXtensão da interferência do Legislativo \\ E DO JUdiciáRIO NAS QUESTÕES DE IMPRENSA}

A possibilidade de interferência do Legislativo e do Judiciário é aceita por boa parte dos ministros, mas a questão é saber se essa intervenção pode ir até disciplinar o conteúdo 
do que será publicado pela imprensa (resposta “C”) ou se ela deve estar limitada às questões ditas "laterais" (resposta "B").

A análise dos votos integrantes da ADPF 130, com o auxílio da tabela em anexo, permite obter uma resposta segura a essa pergunta. Nesse julgamento, os ministros referiram-se ao conceito de "lei de imprensa" como sendo aquela lei que disciplina a imprensa em seus mais diferentes âmbitos, não apenas nas questões ditas "laterais" ou "reflexas". Em outros termos, a "lei de imprensa" seria aquela que dispusesse não apenas sobre a responsabilidade dos meios de comunicação e sobre o direito de resposta, mas, também, sobre o conteúdo do que é publicado. A questão do conteúdo que constitui o cerne da atividade da imprensa - é o elemento-chave que permite compreender a dissidência aberta pelos Ministros Gracie e Barbosa. Estes últimos admitiram a possibilidade de o Estado proibir a publicação de determinados conteúdos (a exemplo da incitação à guerra e do racismo, v. Q 6). Foi por essa razão que eles votaram pela não recepção da Lei n. 5.250 com a ressalva de alguns artigos (v. tabela, Q 1). Já o Min. Britto e outros integrantes da maioria entenderam que os artigos ressalvados pelos Ministros Gracie e Barbosa também não haviam sido recepcionados pela Constituição de 1988, pois o Estado não poderia dizer à imprensa o que ela poderia publicar.

A questão que se coloca, portanto, é a de saber se seria possível ao Estado determinar o conteúdo da liberdade, ou seja, aquilo que um meio de comunicação pode ou não pode publicar (o "quê" insuscetível de mediação estatal, nos termos expressos na fundamentação do relator da ADPF). ${ }^{9}$ Caso se entenda que o legislador pode entrar nesse âmbito, competirá logicamente ao Judiciário analisar os casos concretos à luz da legislação aplicável e da Constituição. Portanto, a definição da extensão possível de interferência do legislador conduz à escolha entre resposta "C" e resposta "D".

Dos sete ministros que integram a maioria que levou à procedência da ADPF 130, dois compartilham, claramente, a fundamentação, pois o Min. Grau acompanhou, sem reservas, o voto do relator (v. tabela, Q 1 e 2). Ambos afirmam claramente ser inconstitucional toda "lei de imprensa", ou seja, toda lei que discipline a imprensa em seus mais diferentes âmbitos, inclusive quanto ao conteúdo do que será publicado (v. tabela, Q 5).

A esses dois, cumpre acrescentar a Min. Cármen Lúcia, que acompanhou o Min. Britto em todos os tópicos sobre os quais ela se manifestou (v. tabela, Q 1, 2, 3, 4, 7 e 10) sem indicar qualquer ponto específico de divergência. Observe-se que, muito embora admita, em tese, que uma "lei de imprensa" possa ser constitucional, ela não fornece qualquer indicação sobre os campos que seriam abertos ao legislador (Q 6). Além disso, ela afirma expressamente que "[a] regulação tem espaço onde não há liberdade" (ADPF 130, p. 330), o que torna sua posição muito próxima à do Min. Britto no sentido de que a regulação do conteúdo estaria vedada ao legislador (v. tabela, Q 4 e 5). 
Quanto ao Min. Lewandowski, já se observou que, com relação à possibilidade de intervenção do Estado-legislador, seu voto parece encaixar-se mais na resposta "A". Essa é a principal especificidade de seu voto com relação ao voto do relator na ADPF 130 (v. supra e tabela em anexo, Q 6). Nos demais pontos, de modo geral, o Min. Lewandowski acompanhou o relator (v. tabela, Q 1, 2, 3, 4, 5 e 7). Com relação à intervenção do Estado no conteúdo do que é publicado, o Min. Lewandowski não chegou a dizer, na ADPF 130 , se seguia ou não o voto do relator (Q 10), questão que será esclarecida por ele em outro momento, como se verá na segunda parte do presente estudo.

O Min. Celso de Mello também acompanhou o Min. Britto na ADPF 130 (v. tabela, Q 2 e 7), o que o aproxima da posição defendida pelo relator. No entanto, no momento preciso de analisar a questão da possibilidade de o Estado interferir na escolha do conteúdo objeto de publicação, ele afirmou que nem tudo poderia ser dito pela imprensa, ou seja, que há determinados conteúdos cuja divulgação poderia ser proibida pelo Estado. Para o Min. Celso de Mello, "nenhuma autoridade pode prescrever o que será ortodoxo em política (...) nem estabelecer padrões de conduta cuja observância implique restrição aos meios de divulgação do pensamento" (ADPF 130, p. 156), mas "isso não significa (...) que a prerrogativa da livre manifestação do pensamento ampare exteriorizações contrárias à própria lei penal comum, pois o direito à liberdade de expressão, que não é absoluto, não autoriza condutas sobre as quais já haja incidido (...) juízo de reprovabilidade penal que se revele em tudo compatível com os valores cuja intangibilidade a própria Constituição da República deseja ver preservada” (ibidem, p. 161). Ademais, "a incitação ao ódio público contra qualquer pessoa, povo ou grupo social não está protegida pela cláusula constitucional que assegura a liberdade de expressão” (ibidem, p. 159).

Percebe-se clara divergência com o Min. Britto, para o qual todos os conteúdos hão de ser admitidos (v. tabela, Q 10). Essa diferença de entendimento permite compreender a razão pela qual os dois ministros em questão votaram em sentidos opostos no HC 82.424 (v. tabela, Q 11). Outro ponto de divergência entre os dois é relativo ao equilíbrio entre liberdade de imprensa e outros direitos fundamentais (v. tabela, Q 9 e diálogo nas páginas 201-204 da ADPF 130). Como se vê, justamente sobre a questão da possibilidade de o Estado fixar temas proibidos, não há uniformidade de entendimento entre esses ministros.

Com relação ao Min. Direito, observe-se, inicialmente, que ele faz referência, em seu voto na ADPF 130, ao "princípio da reserva qualificada” (p. 93), o que já deixa transparecer seu entendimento favorável ao papel do Estado-legislador. Ademais, depois de proferir seu voto, que se encontra nas páginas 85 a 94, ele voltou a tratar da questão relativa ao papel do Estado no final da sessão de julgamento (p. 271-272). Nessa ocasião, ele ponderou que, em sua opinião, todos os votos admitiam a possibilidade de intervenção do Legislativo. O Min. Britto (CB) contestou essa interpretação, lembrando que havia diferentes fundamentos para a não recepção da Lei n. 5.250. A esse argumento, 
o Min. Direito (MD) respondeu dizendo que, embora não fosse necessário, o fundamento que ele havia avançado era "possível”. Confira-se: MD: “a Corte (...) em nenhum momento assinalou a vedação da atividade legislativa. A fundamentação que a Corte adotou foi exatamente num outro sentido" (ADPF 130, p. 271). CB: "Há outras fundamentações, essa não é a necessária” (ibidem, p. 272). MD: “Que é possível. (...) em todos os votos o que perpassou foi essa ideia de que não existe vedação legislativa, mesmo porque a Suprema Corte não pode, num julgamento como este, simplesmente estabelecer uma vedação da atividade legislativa do Estado” (p. 272).

Constata-se que houve divergência quanto à questão de saber se uma nova "lei de imprensa” seria possível. Para o Min. Britto, a resposta é negativa, pois somente as matérias "laterais" poderiam ser disciplinadas, enquanto que, para o Min. Direito, não haveria um impedimento de princípio à intervenção legislativa do Estado.

Por fim, no que tange ao Min. Peluso, os motivos que o levaram a julgar procedente a ADPF 130 são ainda mais distantes daqueles apontados pelo relator desse processo. O Min. Peluso disse expressamente, ao votar com a maioria (v. tabela, Q 1 e 2), que o fazia por outros motivos, deixando consignada sua reserva quanto à fundamentação (Q 4).

A reunião dos votos integrantes da maioria de sete a quatro permite constatar que - no que tange à vedação à intervenção do Estado no âmbito do conteúdo da liberdade de imprensa (o "quê" suscetível de ser publicado) - a fundamentação do voto do Min. Britto na ADPF 130 conquistou, no melhor dos casos, cinco votos, o dele inclusive. Se se considerar a divergência do Min. Celso de Mello com relação à incitação ao ódio (Q 10), somam-se apenas quatro votos. Não houve, portanto, adesão da maioria quanto ao trecho da ementa citado supra (v. item 1.1), o que impede que seja visto enquanto ratio decidendi do STF suscetível de incorporação à "decisão" para efeitos de reclamação.

Por via de consequência, se o STF, enquanto órgão colegiado, não ratificou o entendimento do relator da ADPF 130 de que o legislador estaria proibido pela Constituição de 1988 de interferir no conteúdo a ser divulgado pela imprensa, constata-se que a resposta "D" descrita acima é a que melhor retrata a leitura que o tribunal fez da Constituição. Acrescente-se que o tribunal tampouco ratificou o entendimento do mesmo ministro no sentido de que a Constituição de 1988 teria criado uma preferência pela liberdade de expressão em detrimento dos demais direitos fundamentais (v. tabela, Q 9).

A conclusão a que se chega acerca do conteúdo da "decisão" proferida na ADPF 130 é que ele encontra-se limitado à procedência da ação para declarar a não recepção da Lei n. 5.250 em razão de sua total incompatibilidade com a Constituição de 1988.

\section{ANÁlise do AlCANCE da DECISÃo PROFERIDA NA ADPF 130}

Uma vez compreendido qual é o conteúdo da "decisão" do STF na ADPF 130, cumpre 
analisar o alcance dessa decisão. Para tanto, é importante dar especial atenção às reclamações ajuizadas com base na violação da autoridade dessa "decisão". Essas reclamações têm o mérito de levar os ministros a interpretar seus próprios votos e os de seus pares, a fim de definir o alcance do que foi decidido.

Segundo o art. 10 da Lei n. 9.882, de 3 de dezembro de 1999, a decisão final em ADPF impõe-se "às autoridades ou órgãos responsáveis pela prática dos atos questionados”. A mesma lei abre a possibilidade de que uma reclamação seja proposta em caso de "descumprimento da decisão" (art. 13), hipótese que se aproxima do art. 102, I, l, da CF.

Via processual excepcional, a reclamação testemunha do imenso poder colocado nas mãos do STF. De um lado, ela lhe permite conhecer imediatamente de um caso que, pela via do recurso extraordinário, somente chegaria à sua análise "em última instância” (art. 102, III, CF). De outro lado, a reclamação confere ao STF o poder de cassar "a decisão exorbitante de seu julgado" (art. 17 da Lei n. 8.038, de 28 de maio de 1990). Uma medida tão ágil e com consequências tão severas não encontra equivalente nem mesmo nos países que aderem à regra do precedente, nos quais a eventual desobediência aos precedentes do tribunal situado no topo da hierarquia judiciária não acarreta qualquer sanção jurídica ao magistrado insubmisso. A não submissão ao precedente gera apenas a probabilidade de que a decisão inferior será reformada pela instância superior no âmbito das vias recursais tradicionais. Uma investigação recente realizada sobre a "natureza e autoridade do precedente" chega a conclusão semelhante, afirmando que o precedente possuiria uma força meramente argumentativa, não juridicamente vinculante, inclusive e principalmente na Inglaterra (DUXBURY, 2008, p. 59).

A análise da movimentação processual do STF nos últimos quatro anos revela um número expressivo de reclamações ajuizadas sob a alegação de que o ato atacado estaria desrespeitando a autoridade da decisão proferida na ADPF 130. É possível reunir as reclamações já julgadas em dois grandes grupos: aquelas em que se discute o alcance da não recepção da Lei n. 5.250 e aquelas em que se discutem as consequências com relação à controvérsia em torno da possibilidade de interferência do Estado no conteúdo da informação.

\section{I O ALCANCE DA DECISÃo QUANTO À NÃO RECEPÇÃo DA LEI N. 5.250}

O fato de ter sido afirmada pelo STF a não recepção da Lei n. 5.250 traz diversas consequências práticas, muitas das quais já esclarecidas por reclamações julgadas pelo próprio STF. São analisadas a seguir apenas as mais relevantes.

\section{I. I A impossibilidAde de APlicaÇÃO DA Lei N. 5.250 AOS PROCESSOS EM CURSO}

O principal efeito da não recepção da Lei n. 5.250 é a impossibilidade de sua aplicação a contar da data de julgamento da ADPF 130. O próprio STF já esclareceu que se 
trata de regra absoluta: seja no caso de processos novos, seja no caso de processos já em curso, a lei não recepcionada pela Constituição não pode mais ser aplicada pelos tribunais, nem mesmo aquelas de suas regras consideradas mais benéficas para a imprensa. ${ }^{10}$ Recusa-se, pois, toda e qualquer "ultratividade"11 da Lei n. 5.250.

O fato de ser impossível aplicar a lei não recepcionada não significa que os processos instaurados com base nela devam ser extintos sem julgamento do mérito. Cumpre ao juiz, conforme decisão do STF, dar seguimento aos processos em curso aplicando as regras de direito comum. ${ }^{12}$

Já no caso de haver decisão transitada em julgado que tenha aplicado a lei de imprensa, a superveniência da decisão da ADPF 130 não afeta a execução do julgado. Mesmo se os atos materiais de execução ocorrerem após a decisão da ADPF $130,{ }^{13}$ o STF entende que a prática de tais atos não representa “descumprimento" de seu acórdão. ${ }^{14}$

\section{I.2 A QUESTÃo DOS RECURSOS ESPECIAIS EM QUE SE PEDE}

A APLiCAÇÃO OU A NÃO APLiCAÇÃO DA LEI N. 5.250

O STJ tem lidado com diversos problemas de direito intertemporal envolvendo os recursos especiais em que se pede a aplicação ou a não aplicação da Lei n. 5.250.

Desde os primeiros acórdãos, o tribunal classificou os recursos aguardando julgamento em quatro grupos, buscando seu "aproveitamento"15 a fim de julgar as questões de mérito, sempre que possível, à luz de outros dispositivos infraconstitucionais. Com esse intuito, o STJ tem procurado artigos de lei que possam vir "preencher" o espaço até então ocupado pela Lei n. 5.250.

No entanto, na maioria dos casos, essa busca revela-se infrutífera, pois é da essência mesmo de uma lei especial que suas previsões não encontrem equivalente no direito comum. Essa ausência de norma equivalente tem levado o STJ a não conhecer de diversos recursos especiais, especialmente aqueles em que o recorrente pretende a proteção de direitos então previstos na lei de imprensa, mas insuscetíveis de enquadramento em outras regras infraconstitucionais. Esse seria o caso, segundo o STJ, da publicação da sentença condenatória “em jornal, periódico ou através de órgão de radiodifusão de real circulação, ou expressão, às expensas da parte vencida ou condenada” prevista no art. 75 da Lei n. 5.250.16

No entanto, outro poderia ser o posicionamento do tribunal nesses casos. Mesmo não havendo algum dispositivo legal semelhante, o STJ poderia encontrar um artigo de lei "substitutivo" por intermédio de interpretação extensiva de artigos do código civil ou dos códigos de processo civil e penal. No caso do pedido de publicação da sentença condenatória, seria possível acolhê-lo com base no art. 461 do CPC. O próprio STJ reconheceu, mais recentemente, que, tendo a decisão atacada determinado a publicação da sentença condenatória com base em duplo fundamento (a lei de imprensa e o (PC), a não recepção da lei de imprensa não daria ensejo à rescisão do julgado. Nesse 
caso, que se mostra bastante específico, o CPC seria fundamento suficiente para a mantenção da referida condenação. ${ }^{17}$

A interpretação restritiva que tem realizado o STJ mostra-se ainda mais problemática para as partes em um outro caso: o STJ tem evitado encontrar na Constituição (especialmente no art. $5^{\circ}$, incisos V, IX e X, e no art. 220 da CF) dispositivos que pudessem vir substituir as regras da lei de imprensa. Assim procede, pois o julgamento dos recursos especiais com fundamento direto na Constituição equivaleria a transformá-los em recursos extraordinários e a usurpar a competência do STF. ${ }^{18}$

Estas duas políticas jurisprudenciais do STJ - a interpretação restritiva de dispositivos infraconstitucionais e a não aplicação das normas constitucionais - surgiram em um contexto bastante específico, que é o dos efeitos do julgamento da ADPF 130. Elas tendem a transferir para as mãos do STF praticamente todo o contencioso relativo à imprensa: o contencioso constitucional, que já era de sua competência, e o contencioso até então infraconstitucional que, por força da não recepção da Lei n. 5.250 e da ausência de norma infraconstitucional substitutiva, assume as feições de um contencioso de caráter constitucional.

Cumpre, então, examinar se o STF tem, de fato, assumido esse contencioso ou não.

\section{I.3. O CONHECIMENTO DE RECURSOS DE ESTRITO DIREITO E}

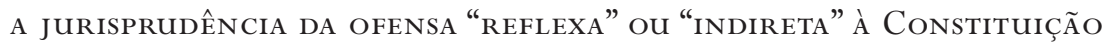

A questão que se coloca é a relativa ao conhecimento dos recursos de estrito direito interpostos até que seja adotada eventual nova lei de imprensa. Na ADPF 130, afirmouse claramente que o fato de a Lei n. 5.250 não ser recepcionada pela Constituição não criaria vácuo jurídico, pois as normas constitucionais já conteriam parâmetros suficientes para preencher o vazio (v. tabela, Q 4 e, especialmente com relação ao direito de resposta, Q 7). Surge a questão de saber se o preenchimento do espaço vazio equivale a uma constitucionalização completa do regime jurídico da imprensa até que advenha nova lei (algo que se poderia chamar de "constitucionalização sob condição resolutiva”). O ponto é de fundamental importância para que as partes saibam qual seria o recurso de estrito direito cabível, se o extraordinário ou o especial.

No âmbito dessa questão, está em jogo a sobrevivência da jurisprudência do STF acerca da ofensa "reflexa” ou "indireta” à Constituição. Segundo essa jurisprudência, não se admite "o recurso extraordinário quando o deslinde da controvérsia dependa do reexame da análise da legislação infraconstitucional, pois, nesse caso, eventual ofensa à Constituição Federal seria indireta ou reflexa”. ${ }^{19}$

Em matéria de imprensa, o STF afirmou, em vários acórdãos, ${ }^{20}$ que a alegação de violação aos dispositivos constitucionais relativos à imprensa não poderia ser conhecida no bojo de recurso extraordinário, pois seria necessário reexaminar a interpretação dada à Lei n. 5.250 pela instância de origem. Dois elementos demonstram a que ponto essa jurisprudência estava perfeitamente consolidada no STF no momento 
em que a ADPF 130 foi julgada. Em primeiro lugar, veja-se que essa jurisprudência foi afirmada ou ratificada por praticamente todos os ministros que votaram na ADPF 130 (v. tabela em anexo, Q 8). Em segundo lugar, observe-se que a questão da não recepção da Lei n. 5.250 pela Constituição de 1988 havia sido suscitada em, pelo menos, quatro dos casos julgados antes da ADPF 130. ${ }^{21}$ Ainda assim, os ministros do STF entenderam que a questão controvertida era de ordem infraconstitucional e que eventual ofensa à Constituição seria somente reflexa ou indireta. Estavam presentes nas sessões de julgamento desses recursos: no AgR no RE 250424, Min. Moreira Alves, Octavio Gallotti, Sepúlveda Pertence e Ilmar Galvão (relator); no AgR no AI 283481, Min. Celso de Mello, Marco Aurélio, Nelson Jobim e Néri da Silveira (relator); no AgR no AI 401888, Min. Carlos Velloso, Gilmar Mendes, Maurício Corrêa e Nelson Jobim (relator); e no AgR no AI 418513, Min. Carlos Velloso, Celso de Mello, Ellen Gracie, Joaquim Barbosa e Gilmar Mendes (relator).

Essa era a situação até o julgamento da ADPF 130, ou seja, na época em que a Lei de Imprensa ainda era aplicada pelos tribunais.

A questão parece colocar-se em termos diferentes a partir da decisão de não recepção da Lei n. 5.250. Uma vez que os tribunais não podem mais aplicar essa lei, não é mais necessário nem possível ao STF fazer o reexame da interpretação dessa lei no momento de julgar o recurso extraordinário. À não recepção da Lei n. 5.250 acrescenta-se o fato de o STJ ter deixado de conhecer de diversos recursos especiais sob o argumento de que não haveria mais questão de lei federal em jogo (cf. supra). Todos esses elementos concorrem para afirmar a natureza eminentemente constitucional das questões jurídicas ligadas à imprensa, pelo menos até que se venha a adotar uma nova lei de imprensa.

Observe-se, ainda, que foi negado seguimento a uma ação cautelar ajuizada no STF em que se argumentava que, diante da não recepção da Lei n. 5.250, não seria mais possível exercer o direito de resposta garantido por essa lei. Para o relator, no entanto, não haveria empecilho ao exercício desse direito, pois o art. $5^{\circ}$ da CF bastaria para dar-lhe efetividade. ${ }^{22}$

Tudo parece levar, portanto, ao abandono da jurisprudência da ofensa reflexa no que tange às questões envolvendo a liberdade de imprensa. No entanto, a despeito de toda a evolução traçada até aqui, o STF vem mantendo a jurisprudência da ofensa reflexa.

Com efeito, em ao menos três oportunidades após o julgamento da ADPF 130, ${ }^{23}$ esse tribunal disse não ser possível conhecer do recurso extraordinário, sob o argumento de que as questões jurídicas ventiladas, inclusive sobre o direito de resposta, ${ }^{24}$ seriam apenas indiretamente de nível constitucional. Observa-se, através desses três casos, que a jurisprudência da ofensa reflexa continua sendo aplicada, sem qualquer modificação ou ponderação, ${ }^{25}$ mesmo depois do julgamento da ADPF 130.

A manutenção dessa jurisprudência gera certa perplexidade. Ela não se concilia muito bem com a solução adotada pelo STF na ADPF 130, no sentido da não recepção 
da Lei n. 5.250. Não havendo mais lei de imprensa, deixa de existir o obstáculo que residia no reexame da interpretação dessa lei para o conhecimento do recurso extraordinário.

Com efeito, o julgamento da ADPF 130 coloca o STF diante da necessidade de tomar uma posição:

- ou se considera que a não recepção da Lei n. 5.250 não cria vazio jurídico (v. tabela, Q 4 e 7), pois a Constituição bastaria para reger as questões jurídicas da imprensa na espera de nova lei -, o que colocaria um termo na jurisprudência sobre a ofensa reflexa nessa matéria e faria do recurso extraordinário a principal via de acesso aos tribunais superiores em questões de imprensa;

- ou se considera que não houve uma constitucionalização completa, o que assegura a sobrevivência dessa jurisprudência, mas acarreta o reconhecimento implícito de que há, sim, espaços de vácuo jurídico, nos quais não seriam cabíveis nem o extraordinário (pois a ofensa seria meramente reflexa) nem o especial (pois, na falta de dispositivo legal aplicável, o STJ tem entendido não ter competência para julgar o caso). Por outras palavras, a ADPF 130 coloca o STF diante de um dilema: ou ele abandona a jurisprudência sobre a ofensa reflexa para os litígios envolvendo as atividades de imprensa e até que seja adotada nova lei, ou reconhece a existência de áreas não regulamentadas, logo, de um vazio suscetível de ataque por via de mandado de injunção ou de ação direta de inconstitucionalidade (ADI) por omissão. ${ }^{26}$

Os próximos passos no cumprimento do acórdão da ADPF 130 certamente darão ao STF a oportunidade de tirar todas as consequências da não recepção da Lei n. 5.250.

Uma vez estudadas, ainda que sumariamente, as principais dificuldades decorrentes da não recepção da Lei n. 5.250, cumpre, agora, verificar qual seria o alcance do acórdão do STF na ADPF 130 com relação ao debate em torno da interferência do Estado no conteúdo da informação a ser divulgada.

\subsection{O ALCANCE DA DECISÃO QUANTO À INTERFERÊNCIA ESTATAL} NO CONTEÚDO DA LIBERDADE DE IMPRENSA

O alcance da decisão do STF com relação ao Poder Legislativo não segue as mesmas regras que o alcance com relação aos demais poderes. Por essa razão, é importante que o primeiro caso seja analisado antes do segundo.

\section{2. i O alcance quanto ao Poder Legislativo}

Na primeira parte deste trabalho, viu-se que, no acórdão da ADPF 130, o STF não chegou a fornecer uma interpretação uniforme da Constituição de 1988 acerca da extensão da competência atribuída ao legislador para disciplinar a atividade da imprensa. Por 
via de consequência, não existe, a esse respeito, qualquer ratio decidendi suscetível de gozar da autoridade de "decisão" para fins de reclamação.

Ainda assim, a questão do alcance da decisão do STF quanto ao Poder Legislativo guarda seu interesse, e por duas razões. Em primeiro lugar, porque é inegável que, em qualquer circunstância, o julgamento do STF possui autoridade persuasiva que pode influenciar a preparação de nova "lei de imprensa”. Torna-se imperioso, portanto, compreender até onde vai o que foi decidido. Em segundo lugar, porque o fato de a jurisprudência do STF ter alargado o conceito de "decisão" (incluindo, assim, a ratio decidendi, conforme exposto na introdução) traz consigo o conflito potencial com a interpretação que o legislador necessariamente faz da Constituição em cada projeto de lei. A partir dessa nova jurisprudência, a interpretação do legislador poderá revelar-se, em um número cada vez mais frequente de casos, diferente daquela “decidida” pelo STF (ou seja, da interpretação subscrita pela motivação da maioria dos ministros, que passa a ser integrada à "decisão" para fins de reclamação). Quando esse conflito vier a se apresentar, poderá o STF obrigar o legislador a submeterse à interpretação que ele (STF) firmou?

É importante esclarecer que a Lei n. 9.882, de 3 de dezembro de 1999, que disciplina a Arguição de Descumprimento de Preceito Fundamental, contém artigos redigidos em termos suficientemente amplos para incluir o Poder Legislativo entre as autoridades às quais se impõe a "decisão" do STF. Nos termos do artigo 10 dessa lei, a decisão final em ADPF será comunicada “às autoridades ou órgãos responsáveis pela prática dos atos questionados, fixando-se as condições e o modo de interpretação e aplicação do preceito fundamental". O parágrafo $3^{\circ}$ desse mesmo artigo atribui à decisão proferida no bojo de uma ADPF "eficácia contra todos e efeito vinculante relativamente aos demais órgãos do Poder Público”. Logo, se o ato questionado em uma ADPF for de hierarquia legislativa, o legislador encontrar-se-ia diretamente afetado. E, considerando-se que a mesma lei abre a possibilidade de que uma reclamação seja proposta em caso de “descumprimento da decisão” do STF (art. 13), poder-se-ia imaginar o seguinte cenário: se fosse firmado em ADPF o entendimento unânime ou majoritário dos ministros do STF no sentido de que a Constituição não autorizaria o legislador a adotar lei sobre determinado assunto (por exemplo, sobre os “temas proibidos" cuja divulgação pela imprensa seria vedada), a inclusão em pauta de projeto de lei contrário a essa interpretação do tribunal seria um "descumprimento da decisão" apto a justificar a competência do STF a cassar "a decisão exorbitante de seu julgado” (art. 17 da Lei n. 8.038, de 28 de maio de 1990)?

Por outras palavras, se o STF viesse a adotar, enquanto órgão colegiado, interpretação de determinado artigo da Constituição e, com base nesse fundamento, julgasse procedente determinada ADPF, seria a leitura da Constituição feita pelo STF uma ratio decidendi capaz de integrar a noção de "decisão" e impedir, por via de consequência, o legislador de votar nova lei que estivesse em confronto com a interpretação já firmada? 
Alguns poderiam dizer que bloquear a aprovação de um projeto de lei significaria realizar controle de constitucionalidade prévio, e que essa competência não teria sido dada ao STF pela Constituição de 1988. Aliás, a ausência dessa competência foi reconhecida pelo próprio STF em um mandado de segurança julgado em junho de 2013. Nesse caso, o impetrante (um parlamentar) pedia que se ordenasse o arquivamento do projeto de lei, sob o argumento, entre outros, de que a interpretação que o projeto atacado fazia da Constituição seria divergente daquela supostamente firmada pelo STF no julgamento da ADI n. 4430. ${ }^{27}$

Um possível contra-argumento consistiria em dizer que a hipótese de uma reclamação não se confundiria com o caso do mandado de segurança, pois ela não requereria do tribunal a realização de controle de constitucionalidade, mas, unicamente, o mero controle do cumprimento de "decisão" anterior do STF. Nesse sentido, note-se que a decisão proferida no bojo da ADPF deve estabelecer, nos termos do artigo 10 da Lei n. 9.882, “o modo de interpretação e aplicação do preceito fundamental”. Essa seria, aliás, uma especificidade da ADPF frente à ADI e à ação declaratória de constitucionalidade (ADC), tendo em vista que a lei que dispõe sobre essas últimas (Lei n. 9.868, de 10 de novembro de 1999) não contém previsão semelhante.

Seja como for, o argumento que parece decisivo para rejeitar a ideia de que a interpretação da Constituição firmada no bojo de uma ADPF impediria o Legislativo de adotar nova lei encontra-se no art. $102, \S 2^{\circ}$, da CF. Nos termos desse dispositivo, a decisão do STF em ADI ou em ADC produz "eficácia contra todos e efeito vinculante, relativamente aos demais órgãos do Poder Judiciário e à administração pública direta e indireta (...)”. Com base nessa norma constitucionale, o STF já decidiu, acerca de uma decisão proferida em ADI, que a eficácia geral e o efeito vinculante "só atingem os demais órgãos do Poder Judiciário e todos os do Poder Executivo, não alcançando o legislador, que pode editar nova lei com idêntico conteúdo normativo, sem ofender a autoridade daquela decisão". ${ }^{28}$ Se o poder Legislativo não é afetado pelo efeito vinculante das decisões em ADI e em ADC, por que o seria em caso de ADPF? Considerando que, até o momento, a jurisprudência não tem feito qualquer distinção entre os parâmetros de controle empregados no bojo de uma ADPF e aqueles válidos no âmbito de uma ADI ou de uma ADC, não parece haver qualquer especificidade na ADPF que justifique um alcance diferente daquele autorizado pela Constituição para a ADI e a ADC. Logo, cumpre dar ao artigo 10, § $3^{\circ}$, da Lei n. 9.882 interpretação conforme ao art. 102, § $2^{\circ}$, da CF.

Chega-se à conclusão de que a decisão do STF proferida na ADPF 130 não produz eficácia contra o Poder Legislativo, seja porque não se chegou a firmar entendimento majoritário acerca da interpretação da Constituição em matéria de imprensa (v. item 1.3 supra), seja porque, ainda que tivesse havido entendimento majoritário, o art. $102, \S 2^{\circ}$, da CF viria limitar a eficácia da decisão do STF aos poderes Judiciário e Executivo. Permanece incólume, portanto, a competência do legislador para adotar, 
se assim entender, nova "lei de imprensa", dentro dos parâmetros previstos pela Constituição de $1988 .{ }^{29}$

\subsubsection{O alcance Quanto aos Demais poderes da República}

Resta o caso da eficácia da decisão com relação aos demais poderes da República, que se submetem, inquestionavelmente, à autoridade da “decisão" proferida pelo STF no bojo de uma ADPF. Já se viu (cf. item 2.1 supra) em que medida o fundamento majoritário da ADPF 130 - ou seja, a incompatibilidade da Lei n. 5.250, em sua integralidade, com a Constituição de 1988 - vincula os demais órgãos do Poder Judiciário.

Com relação à controvérsia em torno da possibilidade de interferência do Estado no conteúdo da informação a ser divulgada, também foi demonstrado (cf. item 1.3 supra) que não houve entendimento majoritário do STF a respeito. Não tendo havido “decisão" acerca desse ponto, a consequência lógica é o descabimento de reclamação contra decisões judiciais ou administrativas que venham criar óbices à publicação de determinada informação. Nada impede, é claro, que sejam utilizados os demais mecanismos processuais existentes para que se venha a tutelar, conforme o caso, a situação de jornalistas eventualmente impedidos ou repreendidos na divulgação de informações. Mas a reclamação, em si, não é cabível, pelo fato de que, nesse âmbito, a autoridade da decisão proferida pelo STF na ADPF 130 não está em jogo.

Foi exatamente nesse sentido que se pronunciou o próprio STF no julgamento da Reclamação n. 9.428. Nesse caso, um jornal de circulação nacional argumentava que o fato de ter sido impedido de publicar matérias sobre um processo correndo em segredo de justiça representaria um descumprimento da decisão proferida na ADPF 130. Segundo o requerente, haveria uma ratio decidendi muito clara na decisão paradigma: a impossibilidade de o Estado interferir na liberdade de imprensa, em especial por meio da censura, o que faria com que toda proibição de publicar determinado conteúdo constituísse uma violação à autoridade dessa decisão.

Por outras palavras, pediu-se ao STF para esclarecer se ele havia, enquanto órgão colegiado, decidido que o Estado não poderia interferir no conteúdo da liberdade de imprensa. Essa reclamação revela-se especialmente interessante, pois foi julgada poucos meses depois do julgamento da ADPF 130 e levou dez dos onze ministros que haviam votado na ADPF 130 a interpretar seus próprios votos e os de seus pares, a fim de definir o que fora decidido nesse último processo. Embora a reclamação sob análise não tenha sido conhecida (por maioria de seis a três), diversos ministros entraram na questão de mérito e pronunciaram-se sobre o que teria sido decidido na ADPF 130. É possível constatar o seguinte:

(i) o relator da reclamação, Min. Cezar Peluso, consignou que entendia não ter havido um posicionamento do colegiado na ADPF 130 que permitisse conhecer da reclamação (v. tabela, Q 12); 
(ii) o Min. Ayres Britto, relator da ADPF 130, defendeu a tese contrária, no sentido de que os ministros teriam concordado que o conteúdo da informação seria insuscetível de mediação estatal. Ele acrescentou que a decisão atacada na reclamação, ao impedir a publicação de determinado conteúdo, somente poderia ter sido tomada com base em aplicação implícita da Lei n. 5.250 e que, nesse sentido, essa decisão afrontaria a autoridade da decisão da ADPF 130. Ele foi acompanhado pelos ministros Celso de Mello e Cármen Lúcia, para os quais o STF como um todo teria tomado uma posição no que tange à censura;

(iii) o Min. Eros Grau, embora tivesse aderido integralmente às razões do Min. Britto na ADPF 130, votou pelo não conhecimento da $\operatorname{Rcl} 9.428$, no que foi acompanhado pelos ministros Ellen Gracie e Gilmar Mendes;

(iv) o Min. Ricardo Lewandowski também votou pelo não conhecimento (Q 12), mas é importante analisar cautelosamente seu caso, pois sua opinião acerca da interferência estatal no conteúdo da liberdade de imprensa não havia sido expressada claramente na ADPF 130 (v. tabela, Q 10). A Rcl 9428 deu-lhe a oportunidade de esclarecer seu entendimento sobre o assunto. Ainda que ele tenha votado pelo não conhecimento da reclamação, observe-se que assim foi por uma questão meramente processual, não por divergência quanto ao mérito da "autoridade" da decisão da ADPF 130. Ademais, curiosamente, como que para eliminar toda dúvida com relação ao seu pensamento, o Min. Lewandowski afirmou de passagem, na Rcl 9428, que ratificava as razões do Min. Britto na ADPF 130 com relação ao conteúdo do que pode ser publicado pela imprensa (v. tabela, Q 12). Mais recentemente, ele teve a oportunidade de confirmar esse entendimento na Rcl 16074 (v. tabela, Q 15);

(v) Por fim, observe-se que o Min. Dias Tofolli, que assumira a cadeira deixada pelo Min. Menezes Direito, não conheceu da reclamação por considerar que conferir tal amplitude à autoridade da decisão do STF traria graves consequências em termos de volume de processo ao STF. Em que pese não conhecer da reclamação, ele consignou que, no mérito, ou seja, quanto à possibilidade ou não de o Estado interferir no conteúdo da liberdade de imprensa, estava de acordo com a posição defendida pelos ministros Ayres Britto, Cármen Lúcia e Celso de Mello (Q 12).

Observe-se que, como demonstrado no item 1.3 supra, sobre a questão da fixação pelo Estado de "temas proibidos", ou seja, a questão de saber se o Estado pode impedir a divulgação de determinado conteúdo, houve concordância de, no máximo, cinco ministros. Mas se se considerar a especificidade do entendimento do Min. Celso de Mello (v. tabela, Q 10 e 11), que diverge do Min. Britto com relação à incitação 
ao ódio e a outras "condutas sobre as quais já haja incidido (...) juízo de reprovabilidade penal" (ADPF 130, p. 159), a concordância de votos fica limitada a quatro ministros. De modo que parece correta a conclusão a que chega o Min. Peluso nesse processo:

Não se extraem do acórdão da ADPF n. 130 motivos determinantes, cuja unidade, harmonia e força sejam capazes de transcender as fronteiras de meras opiniões pessoais isoladas, para, convertendo-se em rationes decidendi determinantes atribuíveis ao pensamento da Corte, obrigar, desde logo, de maneira perene e peremptória, toda e qualquer decisão judicial acerca dos casos recorrentes de conflito entre direitos da personalidade e liberdade de expressão ou de informação. (...) [O acórdão não chega] sequer a propor uma interpretação uníssona da cláusula do art. 220, § $1^{\circ}$, da Constituição da República, quanto à extensão da literal ressalva a legislação restritiva (Rcl 9428, p. 186-187).

A solução dada pelo STF nesse caso (não conhecimento da reclamação) justifica-se, pois, pelo fato de que a proibição de divulgação da matéria envolvendo processo em segredo de justiça não viola a autoridade da “decisão” proferida na ADPF 130. É perfeitamente possível - o que foi ressaltado por alguns ministros - que a proibição de publicação atacada no caso concreto contrarie a Constituição de 1988. Mas a violação da Lei Maior não implica a violação da autoridade das decisões do STF. Eventual contrariedade à Constituição é matéria a ser discutida em recurso extraordinário, não em reclamação.

Posteriormente a essa decisão colegiada, chegaram ao STF outras reclamações que traziam alegações semelhantes à que motivara a $\mathrm{Rcl}$ 9428. Nas reclamações mais recentes, defende-se, de fato, que haveria fundamentos necessários do dispositivo da ADPF 130 que diriam respeito ao conteúdo da liberdade de imprensa e, até mesmo, às questões ditas "laterais". A despeito da solução adotada pelo plenário na Rcl 9428, foi concedida liminar em três dessas reclamações (as de n. 11.292, 15.243 e 16.074), com o fim de suspender as respetivas decisões judiciais de primeira instância.

As liminares deferidas nessas reclamações são novas ilustrações da dificuldade experimentada pelos próprios ministros do STF na identificação do conteúdo da decisão proferida na ADPF 130. É o que se demonstra a seguir.

Reclamação n. 11.292. Para o Min. Joaquim Barbosa, relator do processo, a proibição de divulgação da opinião de que haveria maus tratos a animais pelo uso de sedém no rodeio de Barretos ofenderia a autoridade da "decisão" proferida na ADPF 130, pois "uma das premissas consensuais" deste acórdão seria que "não cabe ao Estado (...) proibir ou regular opiniões", "salvo raríssimas exceções” (v. tabela, Q 13).

Observe-se que o relator dessa reclamação não enumera quais seriam as "raríssimas exceções” fixadas no acórdão da ADPF 130. Limita-se a dar um exemplo, mencionando 
o "discurso do ódio". Ocorre que, na decisão paradigma, o único ministro que menciona expressamente a possibilidade de que o discurso do ódio seja proibido é o Min. Celso de Mello (que fala em “incitação ao ódio público”, v. ADPF 130, p. 159), confirmando a opinião anteriormente exposta por ele no Habeas Corpus n. 82.424 (v. tabela, Q 10 e 11). Nenhum outro voto na ADPF 130, nem sequer o do Min. Joaquim Barbosa, trata da questão de saber se o “discurso do ódio" pode ou não ser proibido. É verdade que esse último ministro apontou, em seu voto na ADPF 130, que a "propaganda de guerra" poderia ser proibida (no que foi acompanhado pelos Min. Ellen Gracie e Gilmar Mendes; v. tabela, Q 1 e 6), mas não foi esclarecido, em nenhum momento, se o "discurso do ódio" seria equivalente à "propaganda de guerra". E mesmo que se considerasse que esses termos designam um único e mesmo objeto, chegar-se-ia a apenas quatro votos relativos ao "discurso do ódio", número insuficiente para caracterizar a opinião do tribunal em seu conjunto.

Reclamação n. 15.243. Para o Min. Celso de Mello, relator do processo, a condenação ao pagamento de indenização pela divulgação de reportagem supostamente ofensiva a um banqueiro violaria a autoridade da "decisão" proferida na ADPF 130, tendo em vista que "não caracterizará hipótese de responsabilidade civil a publicação de matéria jornalística cujo conteúdo divulgar observações em caráter mordaz ou irônico (...), ainda mais se a pessoa a quem tais observações forem dirigidas ostentar a condição de figura pública, investida, ou não, de autoridade governamental” (p. 8 da decisão liminar). Ao longo da fundamentação, o ministro relator reitera trechos de seu voto na ADPF 130, em especial a passagem que afirma que "nenhuma autoridade $(. .$.$) pode (. .$.$) estabelecer padrões de conduta cuja observância implique restri-$ ção aos meios de divulgação do pensamento" (v. tabela, Q 14). Ao final, assevera que "Todas as observações que venho de fazer (...) prendem-se ao fato de que esses temas foram examinados ao longo [da ADPF 130]" (p. 10 da decisão liminar).

Observe-se, inicialmente, que a decisão atacada na reclamação não havia imposto qualquer proibição de divulgação de informações. Tratava-se de ação de indenização por matéria já divulgada. Note-se, em segundo lugar, que a ideia da impossibilidade de "restrição aos meios de divulgação do pensamento" conquistou um número de votos ainda menor do que o argumento da impossibilidade de interferência do Estado no conteúdo da liberdade de impresa (o qual, como se viu, teve a adesão de, no máximo, cinco ministros). Na verdade, o único ministro que defendeu expressamente a impossibilidade de "restrição aos meios de divulgação do pensamento" foi o próprio Min. Celso de Mello (v. ADPF 130, p. 156). Em nenhum momento foi afirmado pelo tribunal, enquanto órgão colegiado, que os jornalistas não poderiam mais ser condenados a pagar indenização pela publicação de suas reportagens. Pelo contrário, até mesmo o relator da ADPF 130, depois de afirmar que o Estado não poderia impedir a publicação de informações (o que ele entende ser o "conteúdo" da liberdade de imprensa), consignou que era possível ao Estado condenar civil e penalmente os responsáveis 
por uma publicação, uma vez realizada (trata-se do âmbito que ele denominou de questões "laterais" ou "reflexas"). Não há qualquer sentido, portanto, em se imputar ao colegiado aquilo que foi exteriorizado por apenas um de seus integrantes.

Reclamação n. 16.074. Para o Min. Ricardo Lewandowski, que, no exercício da presidência do STF, deferiu a liminar nesse caso, a proibição de divulgação de informações sobre determinado advogado descumpriria a "decisão" proferida na ADPF 130, uma vez que "não há liberdade de imprensa pela metade ou sob as tenazes da censura prévia” (v. tabela, Q 15).

A concessão dessa liminar também está em desconformidade com o que foi objeto de decisão na ADPF 130, na medida em que não houve posicionamento majoritário nesse último processo acerca dos casos em que seria possível ao Estado proibir a divulgação de informações e daqueles em que não seria possível fazê-lo (v. tabela, Q 10). Tampouco houve posicionamento majoritário acerca da questão de saber se a Constituição teria criado uma preferência pela liberdade de expressão frente a outros direitos fundamentais (v. tabela, Q 9). Na realidade, a liminar concedida na Reclamação n. 16.074 é não apenas uma ilustração a mais da maneira como os ministros do STF divergem acerca do que teria sido decidido na ADPF 130, mas também do modo como a interpretação que o Min. Lewandowski confere a este acórdão vem variando ao longo do tempo. Lembre-se, como visto, que ele votou pelo não conhecimento da Reclamação n. 9.428, sob o argumento de que "é preciso que haja uma estrita correspondência entre o ato reclamado e a decisão paradigma” (Rcl 9428, p. 241) e que "o que se decidiu [na ADPF 130] foi exatamente a não recepção da lei de imprensa pelo atual ordenamento constitucional. E mais: remeteu-se o trato da matéria à legislação ordinária substantiva e adjetiva, civil e penal” ( $\operatorname{Rcl} 9428$, p. 242). Já na Reclamação n. 16.074, esse mesmo ministro não apenas conheceu do pedido como deferiu a liminar, entendendo que a proibição de divulgação de uma reportagem violaria, em princípio, a autoridade da decisão proferida na ADPF 130. Se a proibição de divulgação de reportagem na Reclamação n. 9.428 não foi considerada uma ofensa à autoridade da decisão proferida na ADPF 130, por que a proibição de divulgação de reportagem na Reclamação n. 16.074 o seria? ${ }^{30}$

O deferimento do pedido de liminar nessas três últimas reclamações revela, portanto, que alguns ministros têm dado à decisão da ADPF 130 um alcance que ela não tem, alcance este que parece considerar como ofensiva à autoridade do acórdão proferido na ADPF 130 toda e qualquer decisão judicial que estabeleça limites à liberdade de imprensa.

A atribuição de alcance tão amplo a uma decisão do STF - cujo conteúdo, no caso, revelou-se limitado à procedência da ação para declarar a não recepção da Lei n. 5.250 com fundamento em sua incompatibilidade integral com a Constituição - tem o condão de retirar todo o interesse que poderia haver na leitura dos acórdãos desse tribunal. Pouco importaria, no fundo, o que o STF efetivamente disse na combinação dos votos 
integrantes de determinado acórdão, pois, uma vez publicado o aresto, poder-se-ia dar-lhe as mais variadas interpretações. A eventual confirmação dessas liminares pelo plenário viria inverter a própria razão de ser da reclamação: ao invés da preservação da "autoridade das decisões" do STF (art. 102, I, 1, da CF), a reclamação passaria a servir à revisão dessas decisões, que perderiam, assim, toda sua autoridade.

\section{Conclusão}

Este artigo procurou demonstrar que o conteúdo da "decisão" do STF na ADPF 130, cujo "descumprimento" é suscetível de ser questionado por reclamação, foi tão somente o de julgar procedente a ação, por maioria de sete a quatro, para fins de se declarar a não recepção da Lei n. 5.250, sendo que seis ministros integrantes da maioria fundamentaram seu voto na incompatibilidade da integralidade desta lei com a Constituição de 1988. O alcance normativo desta "decisão" tem levado o STF a cassar toda decisão que vier a aplicar a referida lei. Além dos diversos casos de direito intertemporal examinados neste trabalho, permanece aberta a questão da sobrevivência da jurisprudência da ofensa reflexa ou indireta à Constituição em matéria de imprensa.

Quanto aos demais motivos adotados ora por um ora por alguns dos ministros, nenhum deles chegou a conquistar a adesão da maioria do tribunal, conforme se depreende da tabela em anexo. Especificamente no que tange à eventualidade de adoção de nova "lei de imprensa" pelo legislador, o acórdão do STF não chega a fornecer qualquer interpretação uniforme ou majoritária que pudesse afetar a competência do legislador na matéria. Continua sendo possível legislar sobre a imprensa, não apenas sobre questões laterais, como pretendia o relator da ADPF 130, mas também sobre o regime jurídico da imprensa em seu conjunto.

Pelos mesmos motivos, não se extrai do acórdão da ADPF 130 qualquer ratio decidendi no sentido da impossibilidade de os demais poderes proibirem a divulgação de determinados conteúdos ou de condenarem ao pagamento de indenização por reportagens já publicadas. Contrariamente ao que têm afirmado algumas liminares deferidas recentemente (v. tabela, Q 13 a 15), essas questões não foram alteradas pelo julgamento da ADPF 130, permanecendo os juízes plenamente competentes para decidir, em cada caso e segundo as normas aplicáveis, acerca da possibilidade ou não de divulgação de certa informação, bem como acerca de eventual responsabilidade civil ou penal do emissor de determinada informação.

: ARTIGO APROVADO (13/11/2013) : RECEBIDO EM 30/12/2012 
ANEXo:

QUESTÕES SOBRE O REGIME JURÍDICO DA IMPRENSA -

TABELA ILUSTRATIVA DOS MOTIVOS QUE INTEGRAM OS VOTOS PROFERIDOS

NA ADPF N. 130, NO HC N. 82.424 E NAS RECLAMAÇÕES N. 9.428, 11.292, 15.243 E 16.074

(ver próxima página) 
146 : CONTEÚDO E ALCANCE DA DECISÃO DO STF SOBRE A LEI DE IMPRENSA NA ADPF 130

\begin{tabular}{|c|c|c|c|c|}
\hline 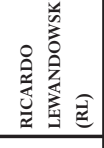 & 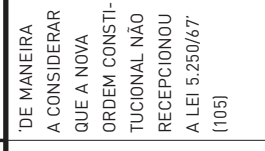 & 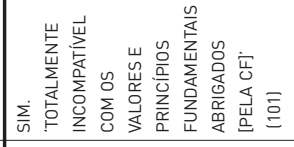 & 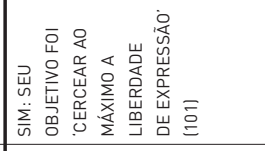 & 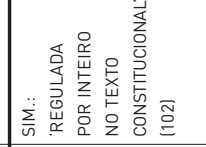 \\
\hline 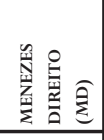 & 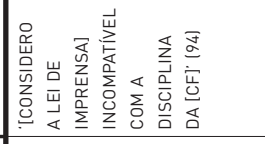 & 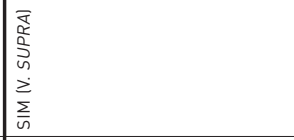 & 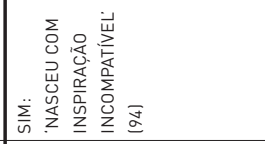 & 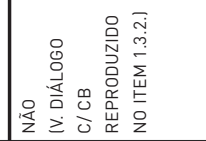 \\
\hline 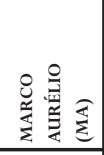 & 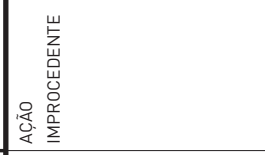 & 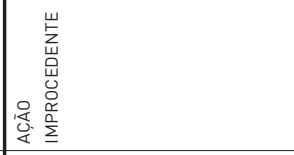 & 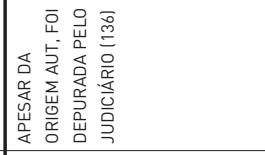 & $\frac{8}{2}$ \\
\hline 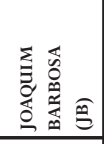 & 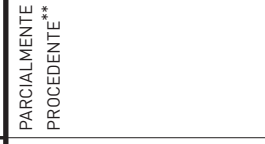 & 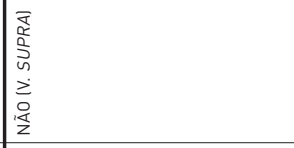 & 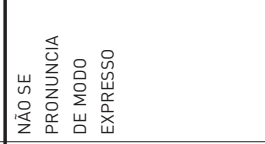 & 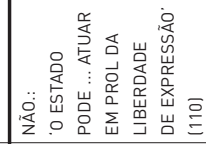 \\
\hline 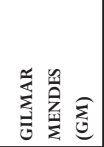 & 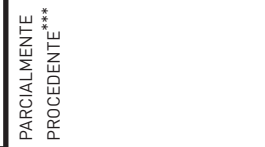 & 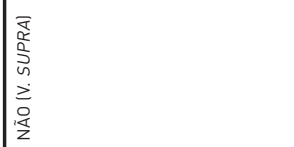 & 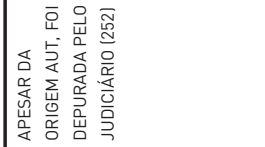 & 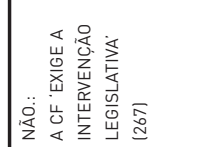 \\
\hline 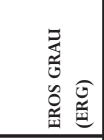 & 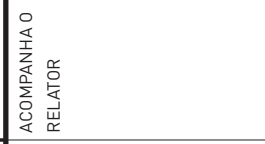 & 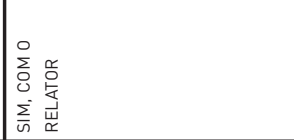 & 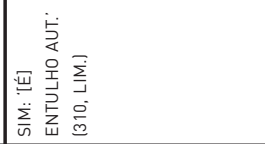 & 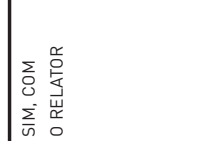 \\
\hline 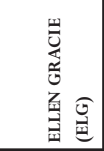 & 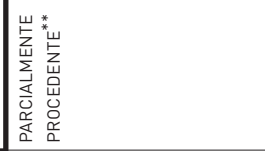 & 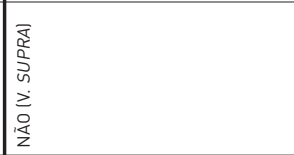 & 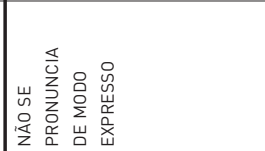 & 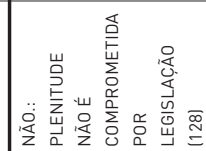 \\
\hline 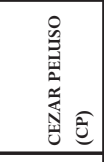 & 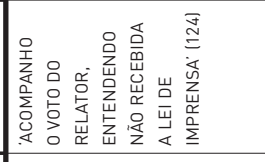 & 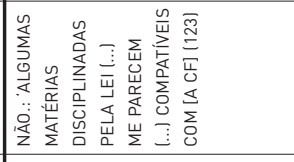 & 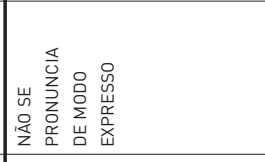 & 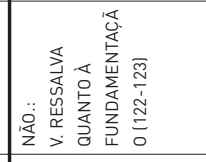 \\
\hline 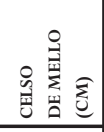 & 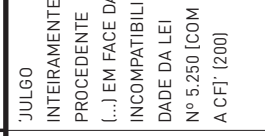 & 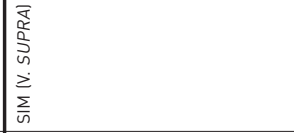 & 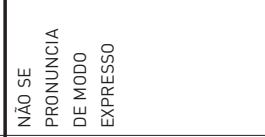 & 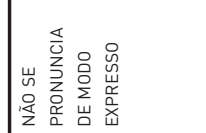 \\
\hline 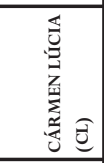 & 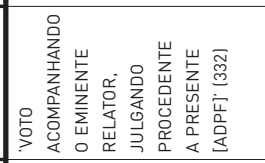 & 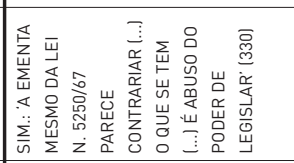 & 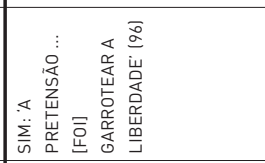 & 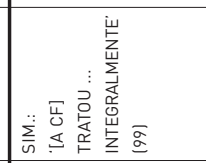 \\
\hline 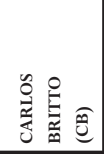 & 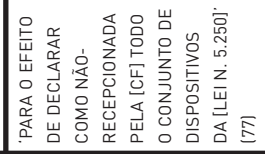 & 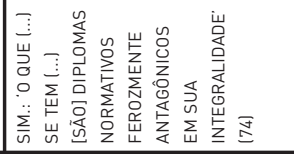 & 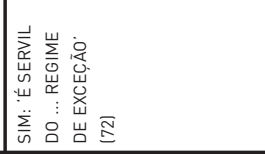 & 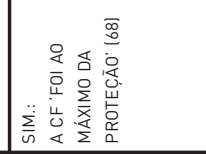 \\
\hline 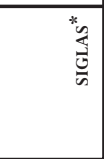 & 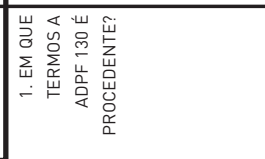 & 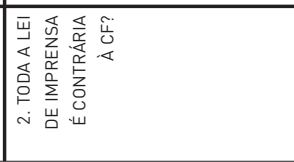 & 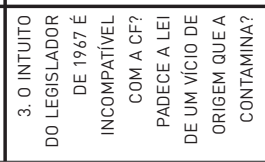 & 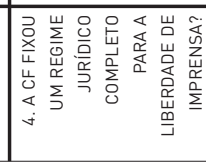 \\
\hline
\end{tabular}




\begin{tabular}{|c|c|c|}
\hline 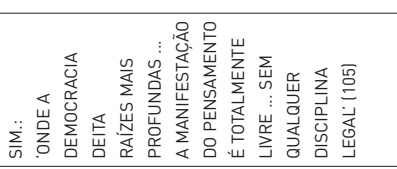 & 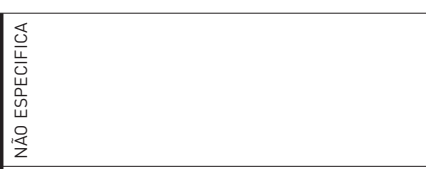 & 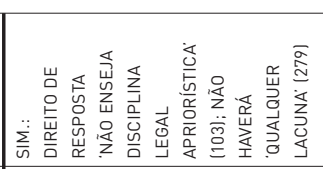 \\
\hline 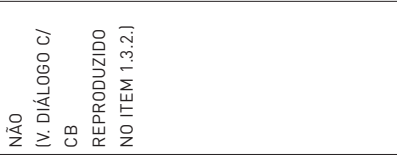 & 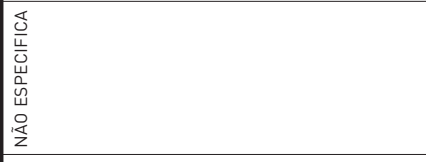 & 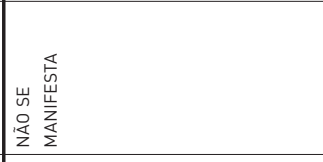 \\
\hline$\frac{8}{2}$ & 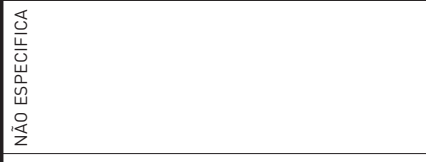 & 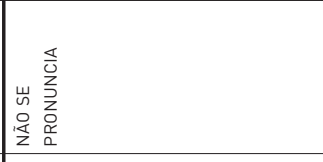 \\
\hline 通 & 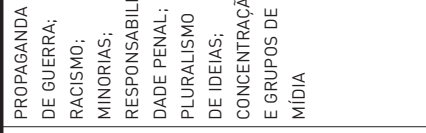 & 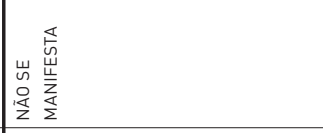 \\
\hline 虽总 & 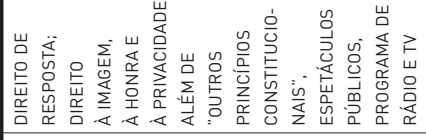 & 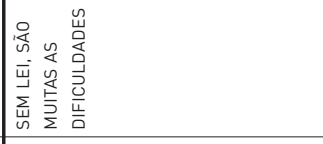 \\
\hline 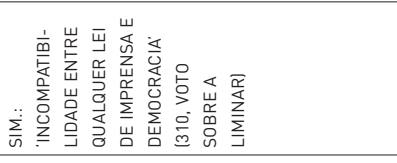 & & 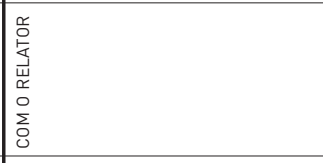 \\
\hline 变 & 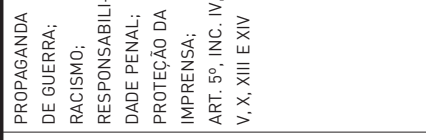 & 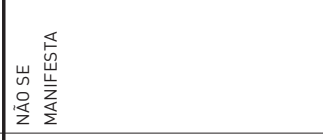 \\
\hline 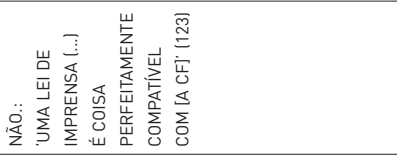 & 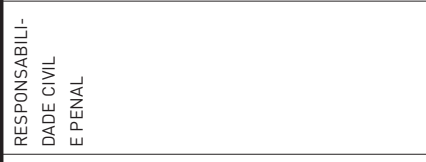 & 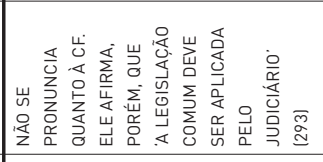 \\
\hline 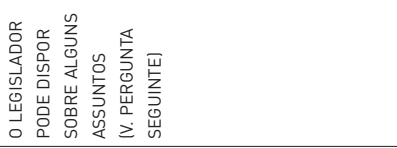 & 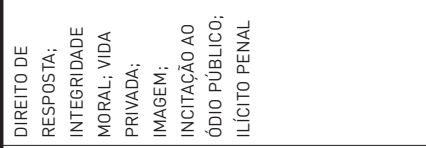 & 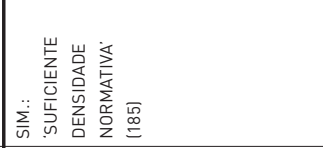 \\
\hline 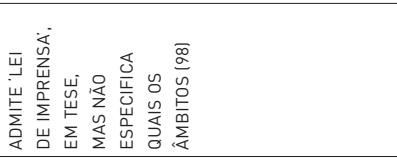 & 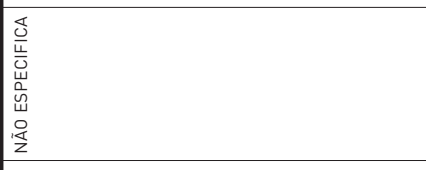 & 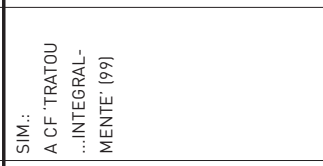 \\
\hline 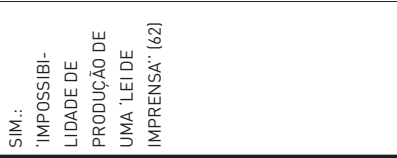 & 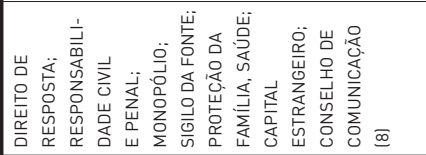 & 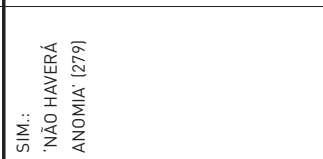 \\
\hline 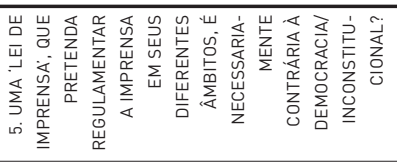 & 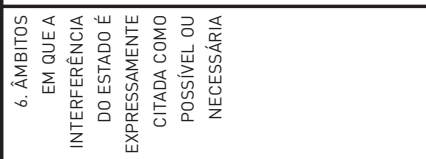 & 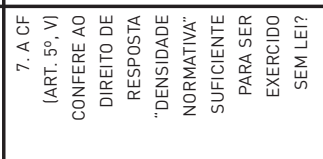 \\
\hline
\end{tabular}


148 : CONTEÚdO E ALCANCE DA DECISÃO DO STF SOBRE A LEI DE IMPRENSA NA ADPF 130

\begin{tabular}{|c|c|c|}
\hline 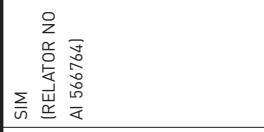 & 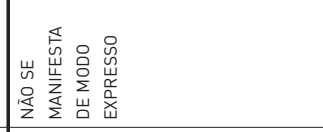 & 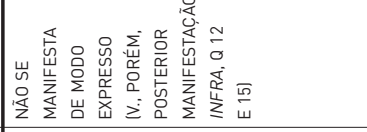 \\
\hline 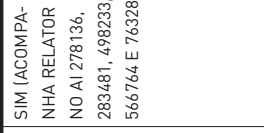 & 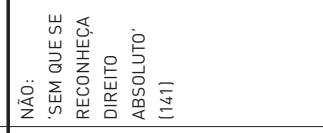 & \\
\hline 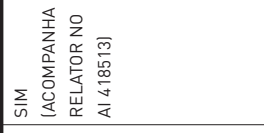 & 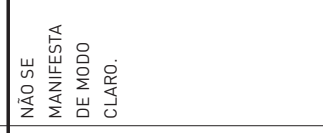 & 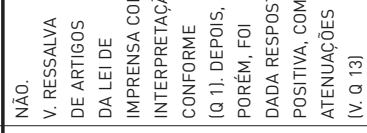 \\
\hline 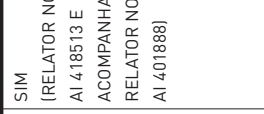 & 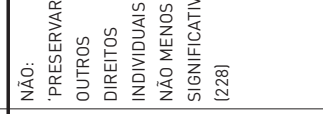 & 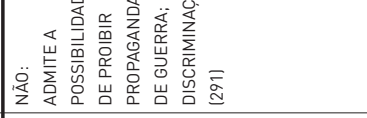 \\
\hline 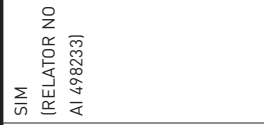 & 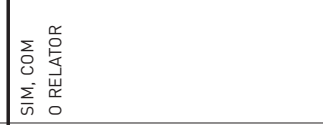 & 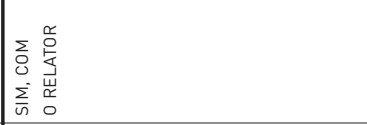 \\
\hline 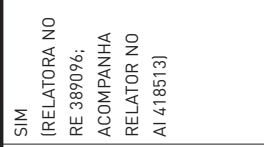 & 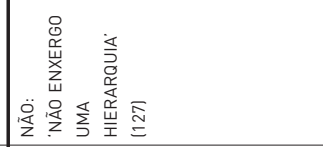 & 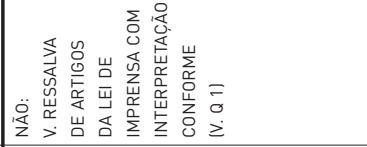 \\
\hline 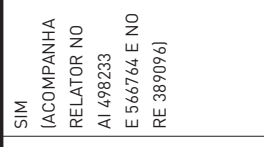 & 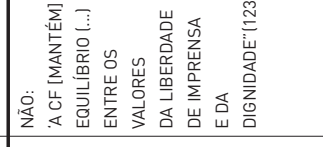 & 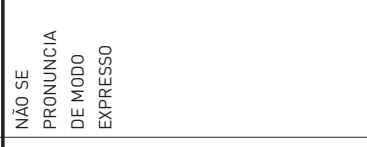 \\
\hline 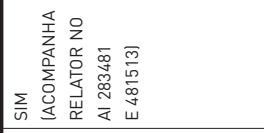 & 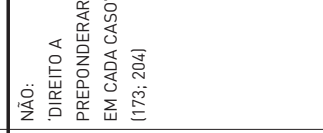 & 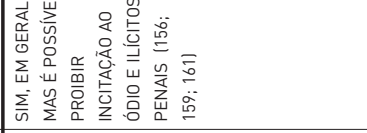 \\
\hline 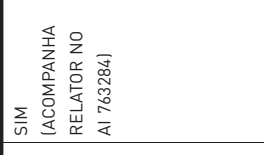 & 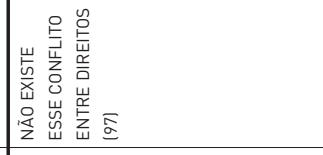 & 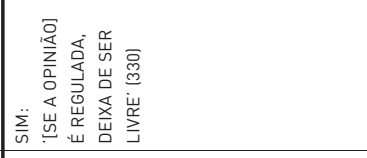 \\
\hline 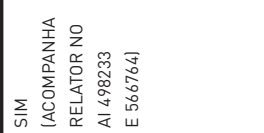 & 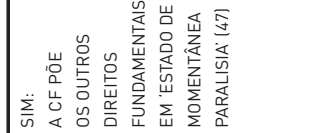 & 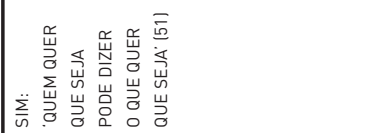 \\
\hline 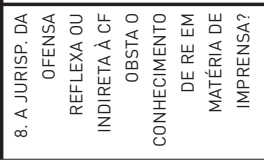 & 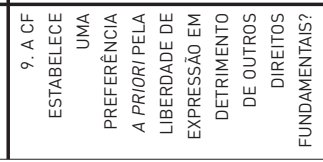 & 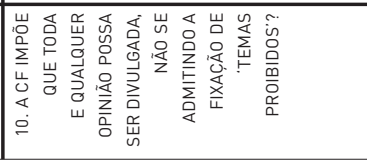 \\
\hline
\end{tabular}




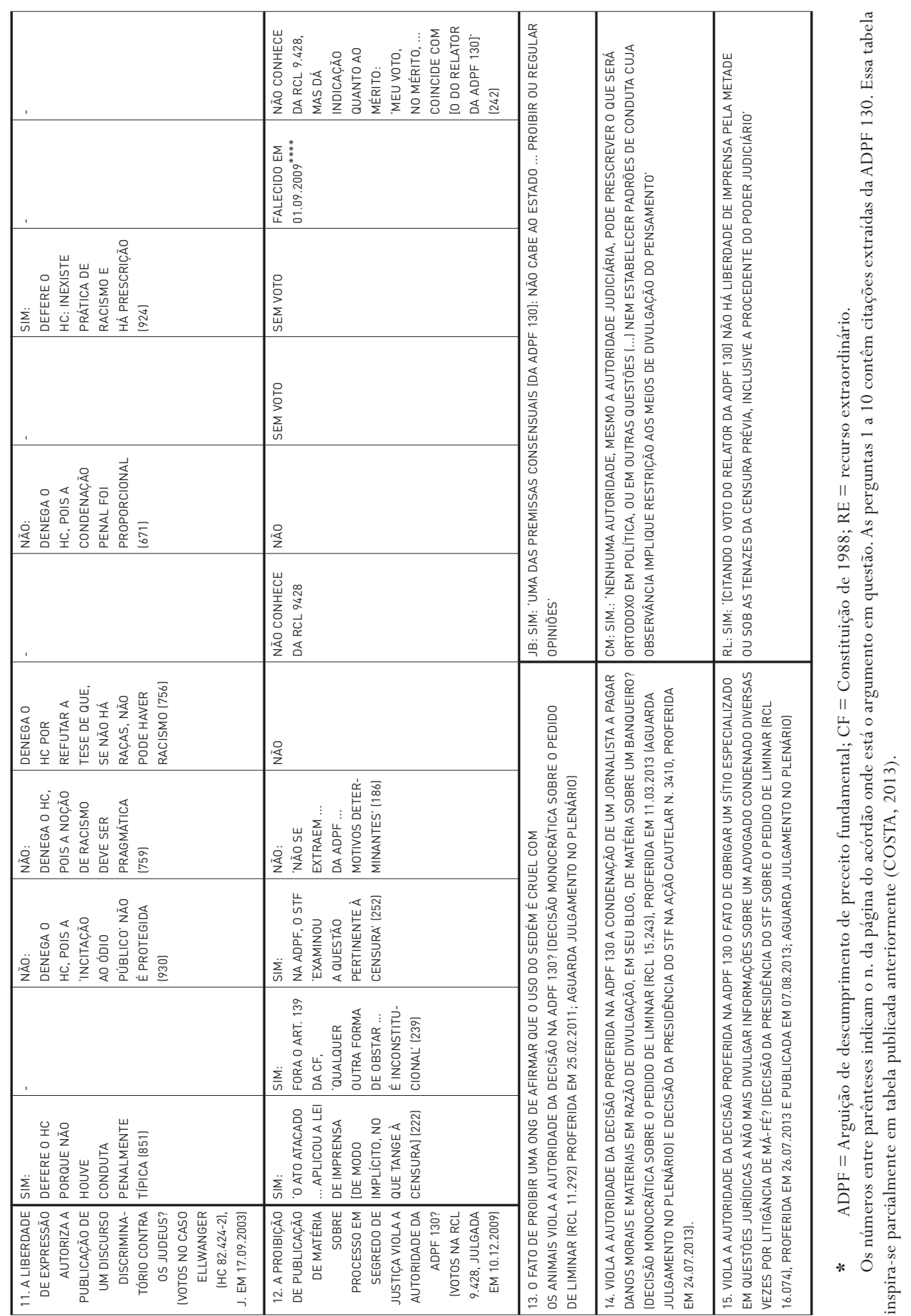




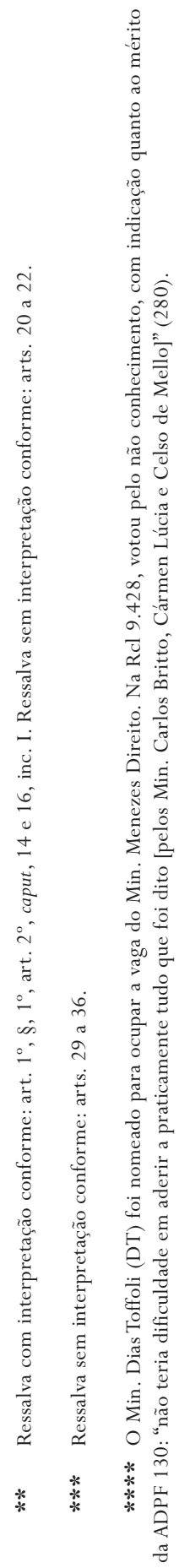




\section{NOTAS}

1 STF, ADPF n. 130, Tribunal Pleno, Rel. Min. Carlos Britto, j. 30.04.2009, DJe n. 208 de 06.11.2009. Para todas as citações de acórdãos do STF contidas neste trabalho, são utilizadas as versões de inteiro teor disponíveis no sítio www.stf.jus.br. Acesso em 30 de setembro de 2013).

\section{AGÊNCIA CNJ DE NOTíCIAS, 2012.}

3 Rcl n. 2.363, Rel. Min. Gilmar Mendes, DJ 01.04.2005; Rcl n. 2.143-AgR, Rel. Min. Celso de Mello, DJ 06.06.2003; Rcl n. 1.987, Rel. Min. Maurício Corrêa, DJ 21.05.2004; Rcl n. 1.722, Rel. Min. Celso de Mello, DJ 13.05.2005; Rcl n. 3.625-MC, Rel. Min. Celso de Mello, DJ 08.11.2005; Rcl n. 3.291, Rel. Min. Cezar Peluso, DJ 31.05.2005; Rcl n. 2.986-MC, Rel. Min. Celso de Mello, DJ 18.03.2005; Rcl n. 2.291-MC, Rel. Min. Gilmar Mendes, DJ 01.04.2003.

4 A título de exemplo, v. Trop v. Dulles, 356 U.S. 86 [1958].

5 A título de exemplo, v. Planned Parenthood of Southeastern Pennsylvania v. Casey, 505 U.S. 833 [1992].

6 Diversos estudos de direito comparado são neste sentido, em especial os publicados pelo Groupe d'études et de recherches sur la justice constitutionnelle e reunidos no Annuaire international de justice constitutionnelle de 1992, p. 163311 e de 2012, p. 11-91. Confira-se também MASTOR, 2005, p. 105-108 e 121-126.

7 ADPF n. 130, p. 8. O trecho destacado em itálico consta em negrito no original. Esse trecho já figurava no voto proferido pelo Min. Britto no HC 82.424, o que revela a ligação entre o HC 82.424 e a ADPF 130, tanto para ele quanto para os demais votantes (v. tabela, Q 10 e 11). Para um estudo detalhado dos votos destas duas decisões, cf. REALE JÚNIOR, 2009, p. 61-91.

8 STF, Rcl n. 9428, Tribunal Pleno, Rel. Min. Cezar Peluso, j. 10.12.2009, DJe n. 116 de 25.06.2010 (os números de páginas citados referem-se à numeração do inteiro teor do acórdão disponível no sítio www.stf.jus.br. Acesso em 30 de setembro de 2013). O diálogo em questão consta na pág. 218 do acórdão.

9 Nas palavras do relator da ADPF n. 130, “... para nossa Constituição, o concreto uso de tais liberdades implica um quando, um quê e um para quê antecipadamente excluídos da mediação do Estado” (p. 63).

10 Rcl. n. 11305 e 11376, Tribunal Pleno, Rel. Min. Gilmar Mendes, j. 20.10.2011, DJ 08.11.2011. As decisões atacadas haviam aplicado o art. 41 da Lei 5.250, sob o argumento de que o prazo de decadência por ele previsto seria mais benéfico ao réu e deveria, portanto, ser aplicado no lugar do direito comum (código penal) em que pese o julgamento da ADPF 130. O STF rejeita, portanto, expressamente, a ultratividade da Lei n. 5.250.

11 Contrariamente à opinião defendida por parte da doutrina (ALONSO, 2010).

12 Rcl 8685, Rel. Min. Celso de Mello, j. 10.03.2010, DJe n. 48 de 16.03.2010. No mesmo sentido, AP 474, Rel. Min. Cármen Lúcia, j. 12.09.2012, DJ 07.02.2013.

13 Rcl. 9.362, Rel. Min. Carlos Britto, j. 19.05.2010, DJ 27.05.2010.

14 A execução da decisão transitada em julgado não pode ser impedida, mas o STJ tem admitido a possibilidade de que a parte prejudicada por uma decisão fundamentada na Lei n. 5.250 possa ajuizar ação rescisória para desconstituir a coisa julgada. O STJ exige, porém, que a Lei n. 5.250 seja o fundamento exclusivo da decisão rescindenda. Na hipótese de esta basear-se em outros dispositivos legais ou constitucionais, a rescisão do julgado deixa de ser possível (AR 4490, $2^{a}$ Seção, Rel. Min. Villas Bôas Cueva, j. 24.10.2012, DJ 29.04.2013).

15 “-Em todas as hipóteses deve-se buscar, na máxima medida, o aproveitamento do recurso e o julgamento do processo. Assim, na primeira hipótese, de aplicação da Lei de Imprensa e de recurso discutindo-a, deve-se procurar decidir a causa aplicando o direito à espécie (art. 257 do RI/STJ). - Na segunda hipótese, em que a parte pleiteia o afastamento da Lei de Imprensa aplicada pelo Tribunal, dá-se provimento ao recurso, salvo hipóteses excepcionais, privilegiando-se a aplicação da norma constitucional em detrimento da norma não recepcionada. - Na terceira hipótese, em que a parte 
pleiteia a aplicação da Lei de Imprensa contra acórdão que não a aplicou, não se conhece do recurso especial, salvo alguma excepcionalidade a ser apurada em cada processo. - Na quarta hipótese, de acórdão fundamentado concomitantemente pela Lei de Imprensa e por outra Lei válida, adora-se uma das seguintes providências: (i) Se o duplo fundamento se refere ao mesmo tema e, no recurso especial, apenas a Lei de Imprensa tenha sido abordada no recurso, mantém-se o acórdão recorrido por força do óbice da Súmula 283/STF, privilegiando-se a aplicação, pelo Tribunal, da lei válida em detrimento da discussão da lei inválida; (ii) Se o duplo fundamento se refere ao mesmo tema e só a parcela da legislação civil for impugnada, conhece-se do recurso especial para discussão desta parcela, descartando-se o fundamento inconstitucional não impugnado, no acórdão; (iii) Se o duplo fundamento se refere a temas diversos, aprecia-se a questão caso a caso, anulando-se o acórdão somente se a aplicação da Lei de Imprensa, devidamente impugnada pela parte, comprometer de maneira definitiva o julgamento, privilegiando a manutenção da um acórdão fundamentado por Lei não-recepcionada.” (REsp 945461, 3ª T., Rel. Min. Nancy Andrighi, j. 15.12.2009, DJe 26.05.2010).

16 REsp 885248, $3^{\text {a }}$ T., Rel. Min. Nancy Andrighi, j. 15.12.2009, DJe 21.05.2010. Diante da não recepção da lei de imprensa, entendeu-se que a referida publicação não seria possível por falta de dispositivo normativo que a impusesse. O STJ afirmou expressamente que essa publicação não integra o direito de resposta e que, por via de consequência, ela não poderia ser ordenada somente com base na garantia constitucional do direito de resposta previsto no art. $5^{\circ}$ da $\mathrm{CF}$. Segundo esse mesmo acórdão, a publicação da sentença condenatória não encontraria tampouco fundamento em outras disposições infraconstitucionais.

17 AR 4490, já citada. Tratava-se, no caso, de ação rescisória de sentença que havia determinado sua publicação na imprensa. O STJ, ao reconhecer que a sentença tinha duplo fundamento, decidiu pelo não cabimento da ação rescisória, com base na súmula 343 do STF.

18 REsp 990079, $4^{\text {a }}$ T., Rel. Min. Luis Felipe Salomão, j. 08.02.2011, DJe 01.07.2011; REsp 942587, $4^{\text {a }}$ T., Rel. Min. Luis Felipe Salomão, j. 02.08.2011, DJe 22.08.2011. Houve interposição de Embargos de Divergência contra o primeiro acórdão mencionado, o qual aguarda julgamento até a presente data.

19 AgRg no AI 482317, 2a T., Rel. Min. Ellen Gracie. J. 22.02.2011, DJ 15.03.2011.

20 O argumento era o seguinte: diante da existência de regulamentação infraconstitucional (ou seja, a Lei n. 5.250), a ofensa à Constituição, se existente, seria meramente reflexa (AgR no RE 250424, $1^{\mathrm{a}} \mathrm{T}$., Rel. Min. Ilmar Galvão, j. 19.09.2000, DJ 02.02.2001; AgR no AI 278136, $2^{\text {a }}$ T., Rel. Min. Nelson Jobim, j. 10.10.2000, DJ 16.02.2001; AgR no AI 283481, $2^{\mathrm{a}}$ T., Rel. Min. Néri da Silveira, j. 31.10.2000, DJ 01.12.2000; AgR no AI 401888, ${ }^{\mathrm{a}}$ T., Rel. Min. Nelson Jobim, j. 22.04.2003, DJ 13.06.2003; AgR no AI 498233, $1^{\text {a }}$ T., Rel. Min. Eros Grau, j. 29.03.2005, DJ 22.04.2005; AgR no AI 418513, 2 ${ }^{\mathrm{a}}$ T., Rel. Min. Gilmar Mendes, j. 13.12.2005, DJ 03.03.2006; AI 590849, $2^{\mathrm{a}}$ T., Rel. Min. Cezar Peluso, j. 08.08.2006, DJ 01.09.2006). As sessões de julgamento em que esses casos foram decididos (todos eles referem-se à liberdade de imprensa) contaram com a presença e o voto de quase todos os ministros que participaram do julgamento da $\operatorname{ADPF}(v$. Q 8).

21 Trata-se do AgR no RE 250424, do AgR no AI 283481, do AgR no AI 401888 e do AgR no AI 418513.

22 STF, Ação cautelar 2695, Rel. Min. Celso de Mello, j. 26.11.2010, DJ 30.11.2010.

23 RE 389096, 2ª T., Rel. Min. Ellen Gracie, j. 08.09.2009, DJe 17.09.2009; AgRg no AI 763284, 1ª T., Rel. Min. Luiz Fux, j. 12.06.2012, DJe 28.06.2012 e AI 846817, Rel. Min. Luiz Fux, j. 29.06.2011, DJ 02.08.2011 (decisão monocrática).

24 Nas palavras do relator do AI 846817, já citado, “fundando-se o acórdão recorrido em interpretação de dispositivos de índole infraconstitucional, in casu, os artigos 29 e 30, incisos I, II e III da Lei de Imprensa, com o intuito de extrair preceitos sobre o direito de resposta ou retificação objetiva que assiste à pessoa acusada/ofendida para defender sua honra e reputação de notícias inverídicas divulgadas pelos meios de comunicação, descabe a esta Corte examinar a questão".

25 Observe-se o destino curioso do RE 389096, já citado: foi-lhe negado conhecimento por decisão monocrática em 16 de março de 2009 sob o argumento da ofensa "reflexa". A parte interpôs agravo regimental, o qual foi julgado somente após o julgamento da ADPF 130. No acórdão prolatado em 8 de setembro de 2009, a segunda turma contentou-se em reiterar os termos da decisão monocrática, ignorando a modificação essencial no ordenamento jurídico decorrente da não recepção total da lei de imprensa, por força da decisão na ADPF 130 de 30 de abril do mesmo ano. 
26 Há uma ação em curso em que se alega que haveria omissão no fato de não haver regulamentação do direito de resposta (ADO 9, Rel. Min. Rosa Weber).

27 MS 32033, Pleno, Rel. Min. Gilmar Mendes, Rel. p/ acórdão Teori Zavascki, j. 20.06.2013, acórdão pendente de publicação.

Trata-se de mandado de segurança em que se buscava impedir a análise de projeto de lei que visava alterar as Leis n. 9.096, de 19 de setembro de 1995, e 9.504, de 30 de setembro de 1997, para prever que "a migração partidária que ocorrer durante a legislatura, não importará a transferência de recursos do fundo partidário e do horário de propaganda eleitoral no rádio e na televisão." Argumentava-se que o projeto de lei em questão violaria uma cláusula pétrea e faria uma interpretação da Constituição diferente daquela que o STF adotara no bojo da ADI 4430.

No caso concreto, a segurança foi denegada por uma maioria de sete a três, tendo os votos majoritários rejeitado a ideia de um controle preventivo de constitucionalidade de natureza jurisdicional. Alguns votos acrescentaram que o vínculo do objeto do projeto de lei com as cláusulas pétreas não parecia estar tão presente a ponto de justificar a aplicação do art. 60 da CF.

28 Rcl n. 2.617, Pleno, Rel. Min Cezar Peluso, v. u., j. 23.02.2005, DJ 20.05.2005.

29 Sobre a oportunidade de nova lei de imprensa, cf. COSTA, 2013.

30 Questão semelhante é levantada na Rcl n. 16.293, referente a uma decisão do Tribunal de Justiça do Paraná que proibiu um jornal de publicar determinada matéria. O pedido de liminar não chegou a ser analisado até o presente momento (30.09.2013).

\section{REFERÊNCIAS BIBLIOGRÁFICAS}

\section{LIVROS, ARTIGOS E OUTROS ESCRITOS}

AGÊNCIA CNJ DE NOTÍCIAS. Fórum do Judiciário vai acompanhar e debater liberdade de imprensa, 08.05.2012. Disponível em <http://www.cnj.jus.br/noticias/cnj/19304:conselheiros-aprovam-criacao-de-forum-sobreliberdade-de-imprensa $>$, Acesso em 30 de setembro de 2013).

ALONSO, Guilherme. A ultratividade da Lei de Imprensa. O Estado do Paraná, caderno "Direito e Justiça" de 07.03.2010. Disponível em <http://www.dotti.adv.br>. Acesso em 30 de setembro de 2013.

COSTA, Thales Morais da. Possibilidade e oportunidade de uma nova lei de imprensa. In: Revista de Informação Legislativa, n. 199, 2013, p. 91-119.

DOTTI, René Ariel. Carta aberta ao Ministro Marco Aurélio. 2009. Disponível em

<http://www.dotti.adv.br/Lei\%20de\%20imprensa\%20Site.pdf>. Acesso em 30 de setembro de 2013.

DUXBURY, Neil. The nature and authority of precedent. Cambridge: Cambridge University Press, 2008. 224 p. GROUPE D'ÉTUDES ET DE RECHERCHES SUR LA JUSTICE CONSTITUTIONNELLE. Les méthodes de travail des juridictions constitutionnelles. Annuaire international de justice constitutionnelle, vol. VIII, 1992, p. 163-311.

. La motivation des décisions des cours constitutionnelles. Annuaire international de justice constitutionnelle, vol. XXVIII, 2012, p. 11-91.

MASTOR, Wanda. Les opinions séparées des juges constitutionnels. Paris: Economica, 2005. 361 p. PFERSMANN, Otto. Rapport français. Le problème des normes paratopiques. In: Fromont, M.; Frison-Roche, M.-A.; Costa, T. M. da; Cerqueira, G. V. da C.; Graeff, B.; Vilariño, T. M. (org.). Droit français et droit brésilien. Perspectives nationales et comparées. Bruxelles: Bruylant, 2012, p. 557-565.

REALE JÚNIOR, Miguel. Limites à liberdade de expressão. Revista Brasileira de Ciências Criminais, v. 81, 2009. p. 61-91.

\section{LEGISLAÇÃO}

BRASIL. Constituição federal de 05.10.1988

BRASIL. Lei n. 5.250 de 09.02.1967 (lei de imprensa)

BRASIL. Lei n. 9.882 de 03.12.1999 (lei que dispõe sobre o processo e o julgamento da ADPF)

BRASIL. Resolução n. 163 do CNJ, de 13.12.2012, DJ-e n. 209/2012, em 14.11.2012 


\section{DECISÕES DE JUSTIÇA}

\section{Supremo Tribunal Federal}

Ação cautelar n. 2695, Rel. Min. Celso de Mello, j. 26.11.2010, DJ 30.11.2010.

Ação cautelar n. 3410, Rel. Min. Celso de Mello, decisão monocrática de 24.07.2013, DJ 07.08.2013.

ADPF n. 130, Tribunal Pleno, Rel. Min. Carlos Britto, j. 30.04.2009, DJe n. 208 de 06.11.2009.

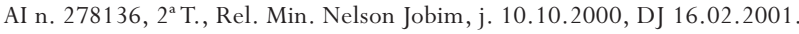

AI n. 283481, $2^{\mathrm{a}}$ T., Rel. Min. Néri da Silveira, j. 31.10.2000, DJ 01.12.2000.

AI n. 401888, $2^{a}$ T., Rel. Min. Nelson Jobim, j. 22.04.2003, DJ 13.06.2003.

AI n. 418513, $2^{\mathrm{a}}$ T., Rel. Min. Gilmar Mendes, j. 13.12.2005, DJ 03.03.2006.

AI n. 482317, $2^{\mathrm{a}}$ T., Rel. Min. Ellen Gracie. J. 22.02.2011, DJ 15.03.2011.

AI n. 498233, $1^{\text {a }}$ T., Rel. Min. Eros Grau, j. 29.03.2005, DJ 22.04.2005.

AI n. 590849, $2^{\text {a }}$ T., Rel. Min. Cezar Peluso, j. 08.08.2006, DJ 01.09.2006.

AI n. 763284, $1^{\text {a }}$ T., Rel. Min. Luiz Fux, j. 12.06.2012, DJe 28.06.2012.

AI n. 846817, Rel. Min. Luiz Fux, decisão monocrática de 29.06.2011, DJ 02.08.2011.

AP n. 474, Rel. Min. Cármen Lúcia, j. 12.09.2012, DJ 07.02.2013.

MS n. 32.033, Rel. Min. Gilmar Mendes, Rel. p/ acórdão Teori Zavascki, j. 20.06.2013, acórdão pendente de publicação.

Rcl n. 1.722, Rel. Min. Celso de Mello, DJ 13.05.2005.

Rcl n. 1.987, Rel. Min. Maurício Corrêa, DJ 21.05.2004.

Rcl n. 2.143-AgR, Rel. Min. Celso de Mello, DJ 06.06.2003.

Rcl n. 2.291, Rel. Min. Gilmar Mendes, DJ 01.04.2003.

Rcl n. 2.363, Rel. Min. Gilmar Mendes, DJ 01.04.2005.

Rcl n. 2.617, Rel. Min Cezar Peluso, j. 23.02.2005, DJ 20.05.2005.

Rcl n. 2.986, Rel. Min. Celso de Mello, DJ 18.03.2005.

Rcl n. 3.291, Rel. Min. Cezar Peluso, DJ 31.05.2005.

Rcl n. 3.625, Rel. Min. Celso de Mello, DJ 08.11.2005.

Rcl n. 8.685, Rel. Min. Celso de Mello, j. 10.03.2010, DJe n. 48 de 16.03.2010.

Rcl n. 9.428, Tribunal Pleno, Rel. Min. Cezar Peluso, j. 10.12.2009, DJe n. 116 de 25.06.2010.

Rcl n. 9.362, Rel. Min. Carlos Britto, j. 19.05.2010, DJ 27.05.2010.

Rcl n. 11.292, Rel. Min. Joaquim Barbosa, decisão monocrática de 25.02.2011, DJ 03.03.2011.

Rcl. n. 11.305 e 11.376, Tribunal Pleno, Rel. Min. Gilmar Mendes, j. 20.10.2011, DJ 08.11.2011.

Rcl n. 15.243, Rel. Min. Celso de Mello, decisão monocrática de 11.03.2013, DJ 20.03.2013.

Rcl n. 16.074, Rel. Min. Roberto Barroso, decisão monocrática de 26.07.2013, DJ 07.08.2013.

RE n. 250424, $1^{\text {a }}$ T., Rel. Min. Ilmar Galvão, j. 19.09.2000, DJ 02.02.2001.

RE n. 389096, $2^{\mathrm{a}}$ T., Rel. Min. Ellen Gracie, j. 08.09.2009, DJe 17.09.2009.

\section{Superior Tribunal de Justiça}

AR 4490, 2 ${ }^{\text {a }}$ Seção, Rel. Min. Villas Bôas Cueva, j. 24.10.2012, DJe 24.04.2013.

REsp 885248, $3^{\mathrm{a}}$ T., Rel. Min. Nancy Andrighi, j. 15.12.2009, DJe 21.05.2010.

REsp 942587, $4^{\mathrm{a}}$ T., Rel. Min. Luis Felipe Salomão, j. 02.08.2011, DJe 22.08.2011.

REsp 945461, $3^{\mathrm{a}}$ T., Rel. Min. Nancy Andrighi, j. 15.12.2009, DJe 26.05.2010.

REsp 990079, $4^{\mathrm{a}}$ T., Rel. Min. Luis Felipe Salomão, j. 08.02.2011, DJe 01.07.2011.

\section{US Supreme Court}

Trop v. Dulles, 356 U.S. 86 [1958].

Planned Parenthood of Southeastern Pennsylvania v. Casey, 505 U.S. 833 [1992].

Thales Morais da Costa

17. Place de la Nation - 75011

Paris - França

costathaleslayahoo.fr
Doutorando EM REgIME DE DUPLA-TITULAC̄̃a NA Université Paris I Panthéon-Sorbonne e na Universidade de São Paulo 